\title{
LEGISLATIVE APPORTIONMENT AND THE FEDERAL CONSTITUTION
}

Scarcely any political question arises in the United States that.is not resolved, sooner or later, into a judicial question.

\author{
-De Tocqueville, Democracy in America
}

\section{ROBERT G. Dixon, JR.*}

The Tennessee state legislature reapportionment case, Baker v. Carr, is a Janusfaced decision. It stands at the end of a long line of judicial refusals to enter the political thicket of reapportionment, so well and so eloquently summarized by Justice Frankfurter in his dissent. As such it evokes memories of lost battles of the past. But the ruling that courts now may entertain challenges to the unrepresentative character of legislatures under the equal protection of the laws clause of the fourteenth amendment seems also to inaugurate a new era for American politics and constitutionalism. Legislative institutions, political theories of representative government, and the unique institution of judicial review will be profoundly affected.

For some the decision in favor of justiciability is a new statue of liberty, signalling a new majoritarianism which will yield new statutory foundations for fresh approaches to urbanism, metropolitanism, and regionalism, for civil rights and liberties, for welfare statism, and even for international relations. For some the decision sounds the death knell on a rule of rural virtue rooted in the mystique of the settler tradition, the log cabin, and the family farm. Others, perhaps more realistic, suggest that the decision has been over-sold despite the immediate flurry of activity it caused in Maryland, ${ }^{2}$ Georgia, ${ }^{3}$ Alabama, ${ }^{4}$ and a number of other states. ${ }^{5}$ They point to institutional obstacles to achieving a flat majoritarianism even with the decision. ${ }^{6}$

- A.B. 1943, Ph.D. (political science) r947, Syracuse University; LL.B. 1956, George Washington University. Professor of Law, George Washington University Law School and Graduate School of Public Law. Member of the District of Columbia bar. Co-author, [with Elmer Plischke] AMERICAN GOverNment (I950), [with John R. Kerstetter] Adjusting Municipal Boundaries: The Law and Practice in 48 STAtes (1959). Contributor to professional periodicals.

The author gratefully acknowledges the aid of the Rockport Fund, and Sam S. Crutchfield, Jr., and George F. Gardner, second-year students in the George Washington University Law School.

${ }^{1} 369$ U.S. 186 ( 1962 ).

2 Maryland Committee v. Tawes, $228 \mathrm{Md}$. 412, I80 A.2d 656 (I962). Impelled by this decision the legislature, in special session, reapportioned the lower house. Washington Post, June $x$, I962, p. I, col. 8, p. 9, col. I. See text infra at notes 274 et seq.

${ }^{3}$ Sanders v. Gray, 203 F. Supp. I58 (N.D. Ga. 1962), appeal docketed, No. 959, 370 U.S. 921 (1962); county unit system invalidated "in its present form" by federal district court. Other suits challenged state legislative apportionment and congressional districts; see notes 267,269 infra.

4Sims v. Frink, 30 U.S.L. WeEK 2512 (M.D. Ala.) (U.S. April I4, 1962); federal district court said that failure of Alabama to reapportion state legislature by July 16 would require court to do so itself; sec text infra at notes $254 \mathrm{et}$ seq.

${ }^{5}$ Within a month and one-half after the Supreme Court decided Baker v. Carr, court action had been taken or was pending in twenty-two states and was being planned in a number of other states. N.Y. Times, May 14, 1962, p. I, col. 2. See text infra at notes 287 et seq.

- In regard to state legislatures, a simple majoritarianism is rendered virtually impossible by such 
They note the prospect of ping-pong litigation with the case bouncing back and forth until the legislature finally makes a tinker the courts will accept, which seemed to be in prospect for Maryland until the governor intervened. ' More fundamentally, they cite empirical studies showing that rural bloc voting obstacles to urban progress in current legislatures may have been exaggerated. ${ }^{8}$

It is, however, no exaggeration to say that in terms of involvement of the judiciary in the politics of the people, and in the great questions of democratic institutional arrangements, the decision is second only to Marbury v. Madison. ${ }^{\circ}$ There the Court first clearly sanctified the American tradition of judicial articulation and enforceability of constitutional principles. It is a more pregnant decision than Brown $\nu$. Board of Education ${ }^{10}$ regarding school desegregation for it involves, as do the social contract philosophies of Hobbes, Locke, and Rousseau, basic choices regarding conditions of political allegiance and expression of public will and opinion. It brings to the surface, as Justice Harlan noted in dissent, unresolved conflicts of principle underlying our expedient arrangements of election districts and legislative assemblies. ${ }^{11}$

common state constitutional requirements (not challenged in Baker $v$. Carr) as minimum and maximum limits, regardless of population; an apportionment of representatives to counties or other units; ceilings on the size of the legislature; traditional use of fixed local units as bases for apportionment; inadequacies in reapportionment machinery. These state constitutional standards will be subservient, of course, to any federal constitutional standards of fair representation.

See Charts I and III in Appendix, regarding bases of representation specified in state constitutions. Regarding built-in inequities, see Durfee, Apportionment of Representation in the Legislature: $A$ Study of State Constitutions, 43 Mich. L. Rev. IogI at IogI-95 (1945). See also Gordon E. Baker, Statz CONSTITUTIONS: REAPPORTIONMENT 5-I4 (1960); Jewell, Constitutional Provisions for State Legislative Apportionment, 8 W. PoLIT. Q. 272 (1955); Dauer \& Kelsy, Unrepresentative States, 44 Nat. Munic. Rev. 57I-75 (1955); Merry, Minority Rule: Challenge to Democracy, Christian Science Monitor, Oct. 2, $1958, \$ 2$, p. I3.

"In what the Washington Post called the "first open display of executive anger at the Legislature during his four years in office," Governor Tawes in the closing hours of the constitutionally limited special session sent a sharp message. It produced a stop-gap bill adding additional seats which for the first time gave the seventy-seven per cent of the population in urban areas a majority (fifty-five per cent) of the seats in the lower house. Until the message, legislators from Southern Maryland and the Eastern Shore, with an odd persistence bred from generations of comfortable overrepresentation, were laboring to bring forth a bill which could have worsened the urban position in the long run. The question of reapportionment for the Maryland Senate is being litigated. Washington Post, June I, I962, p. I, col. 8, p. 9, col. I.

${ }^{8}$ Wheeler \& Bebout, After Reapportionment, $5 \mathrm{I}$ NaT. Civic Rev. (formerly NaT. Munic. Rev.) 246 , 247-48 (1962), citing Derge, Metropolitan and Outside Alignments in Illinois and Missouri Legislative Delegations, 52 AM. PoL. Scr. Rev. 1065 (1958); Young, The 1958 Special Session of the Missouri Genetal Assembly, Missouri Political Science Associstion Newsletter No. 3 (i958).

Even the Maryland legislature's emasculation-by-amendment (prior to Governor Tawes' sharp rebuke, supra note 7) of the court-impelled reapportionment bills may not have been due wholly to the unreconstructed Southern Maryland and Eastern Shore delegates. Urban delegates split and quarrelled, causing the Washington Post (May 30, I962, p. 16, col. I) to comment, with characteristic bluntness, that "the suburb's underrepresentation is not entirely a matter of numbers."

Years ago a long-time student of legislatures observed that "what class feeling appears in the State Legislature is chiefly agrarian." Robert Luce, Legiscative Principles 368 (1930). He also observed that urban delegations sometimes split on party lines, and that parochialism varied inversely with city size. lbid.

${ }_{5}$ U.S. (I Cranch) 137 (1803).

${ }_{10} 347$ U.S. 483 (1954).

11 "In the last analysis, what lies at the core of this controversy is a difference of opinion as to the 
Baker v. Carr calls for a fresh look at bicameralism; the single-member district system; population versus area as bases for representation; traditions of thought and political action geared to counties as historic representative units; the problem of the political artificiality of mathematically equal and frequently changing districts; voting qualifications; the extent to which the one-man-one-vote principle should be universalized in domestic political institutions as distinct from international political institutions; the area, population, and institutional bases of political parties. The list could be extended easily by each social scientist in the context of his own discipline. $^{12}$

In making this fresh look it will be important to have a firm grip on Baker $v$. Carr itself, the malapportionment problem that called it into being, its impact on the line of precedent cases, the crucial and unresolved question of the constitutional standard of fair representation, and judicial means for implementing a standard. It is to these issues, with an occasional look at the peripheral questions, that this article is devoted.

The Judicial Setting:

"Political Questions" and Justiciability

The "political question" doctrine is one of the most tantalizing of all American constitutional law principles, and by nature indefinable because it is really not a "principle" at all. Its elusiveness proceeds from the fact that it is more a rule of expediency than a rule of reason. ${ }^{13}$ It is designed to cover areas where judicial

function of representative government. It is surely beyond argument that those who have the responsibility for devising a system of representation may permissibly consider that factors other than bare numbers should be taken into account. The existence of the United States Senate is proof enough of that. To consider that we may ignore the Tennessee legislature's judgment in this instance because that body was the product of an asymmetrical electoral apportionment would in effect be to assume the very conclusion here disputed. Hence we must accept the present form of the Tennessee legislature as the embodiment of the state's choice, or, made realistically, its compromise, between competing political philosophies." Justice Harlan dissenting, Baker v. Carr, 369 U.S. I86, at 333 (1962).

${ }^{12}$ Regarding state legislatures and theories of representation, see AIFred DE GrazIA, Pubic and Republic (1951); Jefferson B. Fordham, The State Legislative Institution (i959); Robert Luce, Legislative Principles (1930); American Polittcal Science Ass'n, American State Legislatures (Zeller ed. 1954).

${ }^{13}$ Charles G. Post, The Supreme Court and Political Questrons (r936); Field, The Doctrine of Political Questions in the Federal Courts, 8 Minn. L. REv. 485 (r924); Finkelstein, Judicial Self-Limitation, 37 Harv. L. Rev. 338 (I924); Weston, Political Questions, 38 Harv. L. REv. 296 (Ig25). Finkelstein, supra at 344, says that the category of "political questions" applies "to all those matters of which the court, at a given time, will be of the opinion that it is impolitic or inexpedient to take jurisdiction." Field, supra at $485-86$, cautions that "such utility as the study [of political questions] may have will consist, however, in the classification of cases, because conclusions and explanations are often colored to some extent by the viewpoints of the student." Also see Finkelstein, Further Notes on Judicial SelfLimitation, 39 HaRv. L. REv. 22I (I925).

More recent comment reveals little change except a tendency to expand the concept. Frank and panelists, Political Questions, in Supreme Court and Supreme Law 36-47 (Cahn ed. I954). Also see Robert L. Hale, Freedom Through Law I5I-72 (I952); Henry M. Hart \& Herbert Wechsler, The Frderal Courts and the Federal System, x92-97, 207 (x953); Robert H. Jackson, The Supreme Court in the AMerican System of Government 53-62 (I955). 
reason fails for lack of guiding standards, ${ }^{14}$ or judicial power is undermined by prospective inability to shape or enforce a remedy. ${ }^{15}$ It is a self-imposed limitation yielding judicial disengagement either from a given issue or an entire case.

To the cynical, aided by the Court's inability to articulate clearly the metes and bounds of the doctrine, and imbued with the American tendency to wrap judges in the robes of philosopher-kings, the political question doctrine appears as an abdication of responsibility. Others, mindful of the infrequent use of the doctrine, view it as a natural corollary of a system of judicial review. For the practice of an enforceable constitution periodically puts vox populi and higher law in apparent opposition, with the judiciary as uneasy mediator.

Unlike Gertrude Stein's roses, "political questions" are almost infinitely varied. One of the most active categories has been the general disposition to reject suits questioning the apportionment of seats in multi-membered legislative assemblies, the drawing of election district lines, and weighting of votes under electoral college or unit vote plans. Even within this category the judicial precedents cannot be treated meaningfully as a common mass. Many discussions by judges, commentators, and briefwriters suffer from failure to separate state court action from federal court action, state law bases for complaint from federal law bases, and state legislative cases from congressional district cases. Faulty generalizations result, and true precedents are not distinguished from pseudo-precedents.

\section{A. State Court Action}

Filing of a case in a state court rather than a federal court affects the question of justiciability because many state courts do not follow the federal principle of separation of powers and do things which would be clearly outside the "judicial function" under article three of the Federal Constitution. ${ }^{16}$ Being unbound by the federal separation of powers principle, state judiciaries can ignore or stretch the parallel principle in their state constitutions. Some state judiciaries do not shrink from acting in areas where there is no principle of right, but only a bare policy choice of the sort that could and should be made by normal political and legislative processes. A notable example is the Virginia judiciary's municipal annexation activity. In the guise of court "cases" judges order annexation of land to cities,

14 Coleman v. Miller, 307 U.S. 433, 453 (1939); Georgia v. Stanton, 73 U.S. (6 Wall.) 50, 77 (x867, I868). A comment by Justice Jackson, although written in the context of judicial discretion in declaratory judgment proceedings, is likewise relevant here: "But when all of the axioms have been exhausted and all words of definition have been spent, the propriety of declaratory relief in a particular case will depend upon a circumspect sense of fitness informed by the teachings and experience concerning the functions and extent of federal judicial power." Public Service Commission v. Wycoff Co., 344 U.S. 237, 243 (1952). Declaratory judgment cases are among the leading ones exploring the concept of justiciability in situations where jurisdiction and standing are conceded.

${ }^{15}$ Mississippi v. Johnson, 7 I U.S. (4 Wall.) 475, 500-01 (1867).

${ }^{10}$ Robert J. Harris, The Judicial Power of the United States (I940); Arthur T. Vanderoilt, The Doctrine of the Separation of Powers and Its Present-Day Significance (ig53); Dixon, The Doctrine of Separation of Powers and Federal Immunity Statutes, 23 GEo. WAsh. L. REV. 50x, 509-32, 627-40 (I955). 
determine boundaries, and specify conditions. ${ }^{17}$ This "Virginia plan" is much admired by devotees of forcible annexation, and has counterparts in some other states. In many states, however, where the interpretation of the separation of powers principle conforms more closely to the federal interpretation, such unstandardized delegation of policy making to the courts would be unconstitutional. ${ }^{18}$ In the light of this too little recognized facet of state constitutional law, some state court cases on apportionment and districting may not be relevant precedents for justiciability under federal precepts. ${ }^{19}$

There has been much loose citation of precedents even within state judicial systems. For example, the highest courts of New Jersey and Maryland confidently asserted recently that "in 1938, the courts of twenty-two states had exercised the power, or had stated that they had the power, to review legislative apportionment acts upon constitutional grounds. ..."20 The statement is taken from Jones $v$. Freeman, ${ }^{21}$ an Oklahoma case in 1943 in which the court actually held that the separation of powers doctrine barred affirmative relief against the legislature for malapportionment. The Oklahoma Supreme Court had in turn cited the quoted statement to a 1938 article which in turn cited no authorities whatsoever. ${ }^{22}$

${ }^{17}$ Henrico County v. City of Richmond, 106 Va. 282, 55 S.E. 683 (1906). For discussion see Robert G. Dixon, JR. \& John R. Kerstetter, Adjusting Municipal Boundaries: The Law and Practice in 48 Stutes 307-08 (1959); Bain, Annexation: Virginia's Not-So-Judicial System, 15 PUB. Admin. Rev. 251 (1955).

${ }^{18}$ Sec Dixon \& KeRSTETTER, op. cit. supra note $\mathrm{I} 7$, for comments on judicial discretion in the following states: Ark. 54; Idaho 96; Ill. I02; Ind. II 4; Kan. 126; Ky. 134; La. I43; Mich. I59; Minn. I75; Miss. 182; Mo. 186; Mont. I93; Nebr. I97; Nev. 205; N.Y. 219; N.C. 226; Okla. 242; Ore. 248; Pa. 258; S.C. 27I; S.D. 276; Tenn. 28x; Tex. 29I; Utah 299; Va. 307; W. Va. 326, Wyo. 339.

${ }^{10}$ Federal justiciability precepts bind the Supreme Court even in cases brought up from state judiciaries with different perceptions of the judicial function. Nashville, C. and St. L. Ry. v. Wallace, 288 U.S. 249 (1933); Chicago and G. T. Ry. v. Wellman, r43 U.S. 339 (1892).

${ }_{20}$ Asbury Park Press, Inc. v. Woolley, 33 N.J. I, I3-I4, I6I A.2d 705, 7II (I960); Maryland Committec v. Tawes, 228 Md. 412, 431-432, 180 A.2d 656, 666 (1962). The statement is cited also in Appellants' Brief in the Supreme Court in Baker v. Carr, p. 38.

${ }^{21}$ I93 Okla. 554, 560, 146 P.2d 564, 570 (1943). The court denied the request for a mandamus to require the next election to be held under the apportionment as made by the state constitution, and for an order to restrain payment of compensation to legislators already elected under allegedly invalid laws.

The opinion also contained this dictum, somewhat misleading if taken out of context (e.g., Lewis, Legislative Apportionment and the Federal Courts, 7 I Harv. L. Rev. 1057, 1069 n.70 (1958)): "But, though it may be conceded that we have the power to declare all apportionment statutes enacted since statehood void and to require the next election to be held under the apportionment made by the [state] Constitution, it does not follow that we should do so. The result of such action would be to increase the inequality of representation already existing." I46 P.2d 564, 572. Also see Justice O'Neal's comment, dissenting in Romang $v$. Cordell, 243 P.2d 677 (Okla. 1952).

${ }^{23}$ Walter, Reapportionment and Urban Representation, 195 Annals $1 \mathrm{I}-\mathrm{12}$ (1938). Authorities are given in Walter's subsequent article, Reapportionment of State Legislative Districts, 37 ILL. L. REv. 20, 23 (1942), but some are subject to the caveats indicated below. Also see Annot., 2 A.L.R. I337 (19r6).

Since justiciability is seldom mentioned in the state cases, the frequent result of denial of relief may be due really to an unspoken premise about justiciability rather than to a free adjudication of the merits. E.g., People ex rel. Hefferman v. Carlock, I98 Ill. 150, 65 N.E. I09 (1902); Prouty v. Stover, II Kan. 235 (1873). Inadequacy of remedy also looms large even in those state cases which purport to make an adjudication. Brophy v. Suffolk County Apportionment Commissioners, 225 Mass. I24, Ir3 N.E. I040 (rg16); State ex rel. Sullivan v. Schnitger, I6 Wyo. 479, 95 P. 698 (rgo8); State ex rel. Winnie v. Stoddard, 25 Nev. 452, 62 Pac. 237 (1900); Festler v. Brayton, I 45 Ind. 7I, 44 N.E. 37 (1896). 
This same source, however, also contained the statement that no successful cases of judicial control of legislative inaction were found because the separation of powers doctrine prevented courts from interfering "to force the legislature to perform a legislative duty, even if that performance is required by the constitution." ${ }^{23}$ Among the numerous examples available are the series of unsuccessful cases filed in Illinois state and federal courts by John B. Fergus and others in the r920's and 1930's seeking directly or indirectly to compel action by the malapportioned Illinois legislature. Unsuccessful strategies included petitions to mandamus the legislature, ${ }^{24}$ to restrain payment of salaries to legislators, ${ }^{25}$ to institute quo warranto proceedings against legislators, ${ }^{26}$ to bar the governor from certifying congressional elections, ${ }^{27}$ to avoid federal taxes pending federal enforcement of the "republican form of government" guarantee against Illinois, ${ }^{28}$ and to invalidate laws passed by the malapportioned legislature. ${ }^{29}$ Other examples include the Jones $v$. Freeman case itself, ${ }^{30}$ and even the series of Suffolk County cases in Igr 6 which commonly are cited for the proposition that state courts can and have intervened regarding legislative districting. ${ }^{31}$ The Suffolk County cases illustrate the point that courts do not reapportion even when they decide that an existing act is illegal. They must usually revert to a prior act, ${ }^{32}$ which is like Lenin's "one step forward, two steps back,"33 or rely on further action by the legislative body. In Suffolk County there was an invalidation of districts, a mandamus to the county apportionment commissioners, begrudging legislative response from them, a second invalidation and mandamus, a second begrudging legislative response, at which point the Massachusetts court gave up. Population disparity had been reduced from a spread of $\mathrm{r}, 957$ to 6,182 per representative, to a spread of 2,427 to 4,282. The court said: "With some hesitation we are brought to the conclusion that the inequalities of voting power between the several districts ... are not quite so great and the means for avoiding them are not quite so clear as to leave

${ }^{28}$ Walter, supra note 22 , at 13.

21 Fergus v. Marks, 321 Ill. 510, 152 N.E. 557 (I926); Annot., 46 A.L.R. 964 (1927).

${ }^{25}$ Fergus v. Kinney, 333 Ill. 437, I6 4 N.E. 665 (r928), cert. denied, 279 U.S. 854 (1929).

${ }^{26}$ People ex rel. Fergus v. Blackwell, 342 Ill. 223 , x73 N.E. 750 (x930).

${ }^{27}$ Keogh v. Horner, 8 F. Supp. 933 (S.D. Ill. I934).

${ }^{28}$ Keogh v. Neely, 50 F.2d 685 (7th Cir. I93I).

${ }^{20}$ People v. Clardy, 334 Ill. 160 , 165 N.E. 638 (1929). Unsuccessful strategies in other states include action against secretary of state to bar use of challenged districts, State cx rel. Morton v. Zimmerman, 249 Wis. IOI, 23 N.W.2d 6ro (r946); and requests for judicial orders increasing representation in populous areas or reducing it in less populous areas. Waid v. Pool, 255 Ala. 44I, $5 \mathrm{I}$ So.2d 869 (I95I); Burns v. Flynn, I55 Misc. 742, 28I N.Y. Supp. 494 (Sup. Ct. 1935), aff'd mem., 245 App. Div. 799, 28I N.Y. Supp. 497 (3d Dep't r935), aff'd mem., 268 N.Y. 601, I98 N.E. 424 (1935); Romang v. Cordell, 200 Okla. 369,243 P.2d 677 (x952); Latting v. Cordell, x97 Okla. 369, x72, P.2d 397 (1946).

${ }^{30}$ See discussion stupra note 21 .

${ }^{81}$ Attorney General v. Suffolk County Apportionment Commissioners, 224 Mass. 598, II3 N.E. 58I (I9I6); Donovan v. Suffolk County Apportionment Commissioners, 225 Mass. 55, 113 N.E. 740 (I916); Brophy v. Suffolk County Apportionment Commissioners, 225 Mass. 124, 113 N.E. ro40 (1916).

${ }^{32}$ Moran v. Bowley, 347 Ill. I48, I79 N.E. 526 (I932); Williams v. Secretary of State, I45 Mich. 447, 108 N.W. 749 (1906); contra, Jones v. Freeman, supra note 2I (dictum); State ex rel. Schnitger, I6 Wyo. 479, 95 Pac. 698 (rgo8); I8 AM. Jur. Elections $\$ 25$ (1938).

${ }^{33}$ One STEP Forward, Two STEPs Back (1904), analyzing the Second Party Congress. 
fair-minded men in no reasonable doubt that there is a grave and unnecessary inequality between the different districts."

Evaluation of these precedents differs depending on whether one focuses on adjudication of constitutionality in the abstract, which may approach the advisory opinion type of action forbidden in federal jurisprudence, ${ }^{35}$ or focuses on effectiveness of judicial relief, where the general record is barren indeed. ${ }^{36}$ Here again, the degree of precision of the standard of legality, which interacts with the question of feasibility of remedy, may influence the decision to assimilate some cases to the clearly justiciable declaratory judgment category, ${ }^{37}$ others to the more dubious advisory opinion category.

The disposition of state courts to assume even an advisory opinion or declaratory judgment type of jurisdiction in legislative apportionment and districting cases was considerably diminished in the fifteen year period prior to Baker v. Carr. The influence of the Supreme Court's admonition in Colegrove v. Green ${ }^{38}$ in 1946 that courts should stay out of the "political thicket" is apparent, particularly in the later cases. States represented include Wisconsin, ${ }^{39}$ Oklahoma, ${ }^{40}$ Alabama, ${ }^{41}$ Tennessee, ${ }^{42}$ Pennsylvania, ${ }^{43}$ Michigan, ${ }^{44}$ and Mississippi. ${ }^{45}$ The prior disposition to assume jurisdiction but deny affirmative relief seemed to be continued in cases in Wisconsin, ${ }^{46}$

${ }^{34}$ Brophy v. Suffolk County Apportionment Commissioners, supra note 3 r. This Suffolk County litigation, it may be noted, only involved action against county officials, not the state legislature.

${ }^{35}$ Muskrat v. United States, 219 U.S. 346 ( 1911 ). Advisory opinions on constitutional questions are authorized by the constitutions of some states. Field, The Advisory Opinion-An Analysis, 24 IND. L.J. 203 (1949).

${ }^{30}$ Lewis and Walter would concur on this latter point. WALTER, supra notes 22, 23; Lewis, supra note 2I, at 1069. Indeed the section heading in Lewis, "State Experience: Judicial Intervention Can Work," is considerably undercut, if not negated, by his subsequent well-documented summary statement that the "performance of the state courts has been especially weak in fashioning remedies for the wrongful refusal of legislatures to reapportion."

${ }^{37}$ Walter H. Anderson, Actions for Declaratory Judgments (2d ed. T95I); Edwin M. Borchard, DeCLARATORY JUDGMENTS (2d ed, 194I).

${ }^{58} 328$ U.S. 549 (1946).

${ }^{30}$ State ex rel. Broughton v. Zimmerman, 26I Wis. 398, 52 N.W.2d 903 (I952); State ex rel. Martin v. Zimmerman, 249 Wis. xor, 23 N.W.2d 6ox (1946), both citing Colegrove v. Green.

${ }^{10}$ Romang v. Cordell, 200 Okla. 369,243 P.2d 677 (1952); Latting v. Cordell, x97 Okla. 369, x72 P.2d 397 ( 1946 ). Neither cited Colegrove v. Green but Romang relied on the earlier "Fergus" cases in Illinois, supra notes $24-26$, which express the Colegrove principle.

11 Waid v. Pool, 255 Ala. 44I, 5r So.2d 869 (I95r).

${ }^{20}$ Kidd v. McCanless, 200 Tenn. 273, 292 S.W.2d 40 (1956), appeal dismissed, 352 U.S. 920 (1956). The case was a forerunner of Baker $v$. Carr and turned on a narrow point. The chancery court had "simply made a declaration that [Tennessee has] no valid reapportionment statute and then fell back on the de facto doctrine in order to avoid the otherwise necessary conclusion that ... [Tennessee] would no longer have any lawfully elected members of the General Assembly." Id. at 279, 292 S.W.2d at 43. The Tennessee Supreme Court reversed, finding the doctrine inapplicable, and hence, judicial intervention unthinkable.

${ }^{43}$ Butcher v. Rice, 397 Pa. 158, I53 A.2d 869 (1959); Costello v. Rice, 397 Pa. 198, 153 A.2d 888 (1959); companion cases relying on Colegrove v. Green.

"Scholle v. Hare, 360 Mich. $x$, I04 N.W.2d 63 (1960); vacated and remanded (in light of Baker v. Carr), 369 U.S. 429 (1962).

"Barnes v. Barnett, 24I Miss. 206, I29 So.2d 638 (196I), dictum, citing Colegrove v. Green.

${ }^{40}$ State $e x$ rel. Thomson v. Zimmerman, 264 Wis. $644,60 \mathrm{~N} . W .2 \mathrm{~d} 416$ (I953). The court voided on procedural grounds a constitutional amendment on which a new apportionment act was based, thus reinstating the apportionment act of $195 \mathrm{I}$. The constitutional amendment was in violation of the provision that multiple amendments must be voted on separately. 
Washington, ${ }^{47}$ and Florida. ${ }^{48}$ But the first two turned on narrow fact situations and the Florida apportionment was left undisturbed. All of these cases involved state legislative districts. Federal district courts, as would be expected, and the Supreme Court on appeal, followed the Colegrove approach in a number of cases, ${ }^{40}$ prior to the reversal of the federal district court in Baker v. Carr..$^{50}$

Exceptions to the Colegrove-influenced negative response occurred in three cases much discussed in the Baker v. Carr litigation. Two courts-one state and one federal-assumed jurisdiction of state legislative apportionment cases and then postponed decision on the merits to give the legislature opportunity to reconsider the matter. $^{51}$ But in dicta the courts also gave indication that continued legislative inaction would result in invalidation of existing districts and judicial relief in unspecified ways. In a third case, the Hawaiian territorial district court reached the merits and announced orally that it would grant relief without detailing the manner. ${ }^{52}$ Disparaged in Baker v. Carr by Justice Clark as a form of judicial "blackjacking," judicial activity did achieve results in the form of legislative action in all three cases. ${ }^{55}$ The "blackmail" question aside, the crucial issue is whether courts should go adventuring in areas where remedial power may be more hope than reality. Is it sufficient to say that judicial power in major governmental cases always rests on good faith and voluntary compliance anyway? ?to $^{50}$

${ }^{47}$ State v. Meyers, 5r Wash. 2d 454, 319 P.2d 828 (1957). The court left undisturbed a r957 legislative modification of a 1956 initiative approved by the voters regarding apportionment.

${ }^{48}$ Brewer v. Gray, 86 So.2d 799 (Fla. 1956).

40 W.M.C.A., Inc. v. Simon, 202 F. Supp. 74 I (S.D.N.Y. I962), vacated and remanded, 370 U.S. I90 (rg62); Perry v. Folsom, 144 F. Supp. 874 (N.D. Ala. r956). Prior to Baker challenges had been rejected in Supreme Court per curiam opinions as follows: Radford v. Gary, 352 U.S. 991 (1957) (Okla.); Remmey v. Smith, 342 U.S. 916 (1952) (Pa.); Colegrove v. Barrett, 330 U.S. 804 (x947) (IIl.); Cook v. Fortson, 329 U.S. 675 (1946) (Ga.); Turman v. Duckworth 329 U.S. 675 (1946) (Ga.). All involved state legislative districts except the two Georgia cases which involved the county unit system.

${ }^{80}$ The district court had dismissed on authority of Colegrove v. Green. 179 F. Supp. 824 (M.D. Tenn. I959).

${ }^{51}$ Magraw v. Donovan, I63 F. Supp. 184 (D. Minn. 1958); Asbury Park Press, Inc. v. Wooley, 33 N.J. I, 161 A.2d 705 (1960).

${ }^{52}$ Dyer v. Kazuhisa Abe, 138 F. Supp. 220 (D. Hawaii 1956), reversed on other grounds, 256 F.2d 728 (9th Cir. 1958). The Dyer case and the Magraw case (ibid.) are discussed here because they influenced the New Jersey state court in Asbury Park Press (ibid.), and, also under the "Federal Court" heading, text infra at notes $117-20$.

${ }^{53}$ Baker v. Carr, 369 U.S. 186, 260 (1962).

1 d. at 270 .

${ }^{6}$ Subsequent developments are reported as follows: Minnesota case, 177 F. Supp. 803 (D. Minn. 1959); New Jersey case, N.Y. Times, Feb. 2, 1961, pp. I and 16; Hawaii case, Lewis, Legislative Apportionment and the Federal Courts, 71 Harv. L. Rev. 1057, 1088-89 (x958).

${ }^{56}$ Regarding acceptance of judicial curbs on executive action, Youngstown Sheet and Tube Co. v. Sawyer, 343 U.S. 579 (1952) involving presidential seizure, is comforting, but see Prize Cases, 67 U.S. (2 Black) 635 (1863), and Korematsu v. United States, 323 U.S. 214 (1944), where during wartime executive power, albeit concurred in by Congress, was upheld, and Ex parte Milligan, 7I U.S. (4 Wall.) 2 (I866) where the war had been won before the power was negated.

Regarding acceptance of judicial curbs on legislative action, Watkins v. United States, 354 U.S. 178 (1957) likewise is comforting, but use of the Watkins doctrine in more recent contempt of Congress cases has caused rumblings that if the Court continues to free contemnors Congress should resort to direct contempt punishment. 
Dyer $v$. Kazuhisa $A b e^{57}$ although first in time of these three cases, may be lowest in precedent value not only because it involved a relatively narrow standard but also because the court analogized its power as a federal territorial court to the power of state courts over "inferior legislative" bodies such as cities and counties. ${ }^{68}$ Now that Hawaii and Alaska have achieved statehood, Dyer also represents a diminishing category of courts. The court was not state, not federal in the "constitutional court" sense, but federal in the "legislative court" sense, effectuating the will of Congress in the territory. ${ }^{59}$ The challenge to the malapportioned Hawaiian territorial legislature was founded on fifty-five years of noncompliance with the congressional mandate to reapportion from "time to time." Because of the territorial aspect the court felt that Colegrove with its overtones of delicacy of federal-state relations posed no barrier to enforcement of this demand.

On remedies the court was more indefinite. It talked in strong terms of a power to "order affirmative action to readjust legislative districts to population needs," also spoke of the possibility of an election at large. However, having scaled the mountain it found no enemy to repel because, shortly after the court announced it was prepared to grant relief, Congress mooted the matter. By amendment to the Organic Act, Congress redistricted and shifted authority for future reapportionment to the governor, subject to judicial control, ${ }^{61}$ which Hawaii retains in her present state constitution. ${ }^{62}$

Magraw v. Donovan, ${ }^{63}$ like Baker v. Carr, was a petition to a federal district court in Minnesota seeking to use the equal protection of the laws clause of the fourteenth amendment as the lever to achieve reapportionment of the legislature. The stratagem was successful, but the case, like Baker $v$. Carr, in its present posture, throws no light on the crucial question of the substantive meaning of equal protection because the court never had to decide the merits. Its retention of jurisdiction, and its dictum that "it is obvious that substantial inequality exists," action at the next session of the Minnesota legislature. The greater anomaly of how the Minnesota federal district court-a regular "constitutional" court unlike the Dyer court-got around the Colegrove precedent so as even to be in a threatening position, is discussed below. ${ }^{\mathrm{ev}}$

Asbury Park Press, Inc. v. Woolley ${ }^{6 B}$ was simpler than Magraw on the question of standards because it was a petition to a New Jersey state court to enforce a manda-

${ }^{87} 138$ F. Supp. 220 (D. Hawaii 1956), reversed on other grounds, 256 F.2d 728 (9th Cir. 1958).

Es Id. at $234-35$.

${ }^{80}$ On the distinction between "constitutional" and "legislative" courts see works by Harris and by Dixon, op. cit. supra note i6; Henry H. Hart, JR. \& Herbert Wechsler, The Federal Courts and THE FEDERAi Systex ch. 2 generally and 348-72 (I953).

${ }^{00}$ Dyer v. Kazuhisa Abe, supra note 52, at 235.

${ }^{\circ}$ Discussed in Lewis, supra note 55, at xo88-89.

${ }^{\circ}$ Art. III, \$4.

${ }^{68} 159$ F. Supp. 90 (D. Minn. I958), I63 F. Supp. I84 (D. Minn. I958), I77 F. Supp. 803 (D. Minn. 1959).

Q4 163 F. Supp. 184 , at 187 .

"S See text infra at notes IIy-rzo.

${ }^{\circ 6} 33$ N.J. I, 16I A.2d 705 (1960). 
tory duty, imposed by the state constitution, to reapportion every ten years. The plaintiffs here, as in Magraw, sought to avoid the appearance of proceeding directly against the legislature by requesting a declaration that the existing apportionment statute was invalid and an order against its continued use as a basis for elections. ${ }^{07}$ Despite the exactness of the standard and its clear violation by non-apportionment in r $95^{\circ}$ the New Jersey court did not decide the merits although it suggested there might also be a violation of equal protection and discussed various possible remedies. It retained jurisdiction to give the legislature an opportunity to act once the Ig6o figures were available; and the legislature acted.8

A more dramatic example of judicial activism regarding apportionment occurred in Oregon in $196 \mathrm{I}$ when the state supreme court invalidated a reapportionment plan and directed the Oregon Secretary of State to draft a reapportionment in compliance with the state constitution. ${ }^{69}$ To place this case in proper context it must be noted, first, that the state constitution contains detailed mathematical formulae and, second, that the state constitution provides that if the legislature fails to reapportion, it shall be done by the Secretary of State. Judicial review is specifically authorized.

A number of other states, in an attempt to depoliticize reapportionment and avoid the separation of powers impasse, likewise provide for use of the administrative process either as an alternative or a substitute for the legislative process of reapportionment, ${ }^{70}$ sometimes coupled, as in Oregon, with express provisions for judicial review. Effectiveness of these devices as ways of achieving numerically equitable apportionments depends not only on the frequency of their use, but also on the substantive limits which state constitutions place on the discretion of the apportioning body. ${ }^{71}$ Even the administrative process, judicially impelled and reviewed, is no answer to the problem of state apportionment formulae which effectively defeat numerical equality by placing a ceiling on representation from populous counties or provide minimum guarantees for non-populous counties. The federal equal protection principle, if further developed in Baker v. $\mathrm{Carr}^{72}$ and other current litigation, ${ }^{73}$ may override some of the state constitutional commands.

or "Standing" created no problem. The petitioners were residents in Magraw, taxpayers in Asbury Park Press, and a voter in Dyer.

${ }^{88}$ N.Y. Times, Feb. 2, 196I, p. I, col. 2; p. 16, col. 2.

${ }^{\circ}$ In re Review of Chapter 482, Oregon Laws x96r, 228 Ore. 562, 364 P.2d 1004 (I96r); In re Apportionment of Senators and Representatives, 228 Ore. 575, 365 P.2d 1042 (I96I).

${ }^{70}$ See tabulation, Council of State Governments, THE Book OF THE STATEs, 1962-1963 at 58-62 (1962). The fourteen states, and dates of last reapportionment, are: Alaska (1956), Arizona, lower house only (1958), California (I96I), Hawaii (r959), Illinois (I955), Michigan, lower house only (I953), Missouri, lower house only (I96r), New Jersey, lower house only (r96r), North Dakota, lower house only (r96r), Ohio ( $196 \mathrm{r}$ ), Oregon (r96r), South Dakota (rg6r), Texas (rg6r).

For judicial action under these provisions, see Lewis, supra note 55, at rogo. Also see Jeprerson B. Fordham, The State Legislative Institution 46-47 (i959); American Political Science Ass'in, American State Legislatures 4 I-44 (Zeller ed. 1954); American Political Science Ass'n, Report of Committee on Apportionment of Congress, 45 AM. PoL. Scr. REv. 153-57 (1946).

${ }_{71}$ See tabulations of state reapportionment formulae in Charts I-III in Appendix.

72 The Supreme Court did not reach the merits in Baker v. Carr.

${ }^{73}$ See text infra at note 25 I et seq. 
B. Basis of Complaint: State Law, Federal Law

In addition to distinguishing state court action from federal court action it is also important to separate state law grounds for challenging legislative apportionment and districting from federal grounds. State law grounds cover a wide gamut of constitutional and statutory provisions, some quite discretionary but many quite clear and simple. ${ }^{74}$ For example, there may be fixed ceilings on size of the legislature or one house, ${ }^{75}$ fixed ratios between the state senate and state lower house, ${ }^{78}$ mandates to follow town boundaries, ${ }^{77}$ and contiguity requirements. ${ }^{78}$ The federal law basis for challenge to state legislative districts is the elusive "equal protection" guarantee of the fourteenth amendment, augmented possibly by due process considerations. These clauses, it must be stressed, are not even phrased in terms of population considerations. For challenge of congressional districts it is the same broad basis, augmented formerly by the compactness, contiguity, and population requirements of some of the older federal apportionment acts. ${ }^{79}$ Obviously, cases in state courts adjudicating relatively narrow state law standards, which constitute much of the state law litigation, ${ }^{80}$ are of slight relevance to a federal court challenge to a whole legislature under a generalized equal protection theory.

\section{State Legislative Districts-Congressional Districts}

There is also a three-fold need to distinguish congressional district cases from state legislative apportionment and districting cases. First, the degree of precision of the standard of legality is often much greater in regard to some state legislative districts than in regard to congressional districts, as noted above. Second, the theory of representation underlying state legislative districts differs markedly from the theory of representation underlying congressional districts. Population as a classifying principle, uncomplicated by other factors, seems to underlie the federal constitutional principles concerning the House of Representatives. ${ }^{81}$ With the apportionment of seats to the states on a population basis, and changing decennially,

${ }^{7 t}$ E.g., the Oregon, Washington, and Wisconsin cases discussed above, supra notes $69,47,46$, re spectively. And see generally Durfee, Apportionment of Representation in the Legislature: $A$ Study of State Constitutions, 43 Mrch. L. Rev. IogI (1945); Walter, Reapportionment of State Legislative Districts, 37 ILI. L. REv, 20 (I942).

${ }^{76}$ State ex rel. Attorney General v. Francis, $26 \mathrm{Kan} .724$ (I882), invalidating a law passed only with the assistance of the "surplus" legislators from newly organized counties; Adams v. Forsyth and Robertson, 44 La. 130, ro So. 622 (I898); Sandoz v. Sanders, x25 La. 396, 5x So. 436 (r9ro).

${ }^{70}$ Caesar v. Williams, 37 I P.2d 241 (Idaho I962).

77 Tishman v. Sprague, 293 N.Y. 42, 55 N.E.2d 858 (I944).

${ }^{78}$ Shoemaker v. Lawrence, 3 I Pa. D. \& C. 68 I (C.P. Dauphin Cty. I938).

${ }^{70}$ These requirements in the Reapportionment Act of IgII, which was similar to previous acts in the nineteenth century in this respect, were held by the Supreme Court in I932 to have expired. Wood v. Broom, 287 U.S. x (1932); Mahan v. Hume, 287 U.S. 575 (1932).

${ }^{80}$ Durfec and Walter, supra note 74; Annot., 2 A.L.R. I337 (I916).

${ }^{81}$ For an analysis of the historical materials bearing on the "democratic character of the House," see Paschal, The House of Representatives: "Grand Depository of the Democtatic Principle"?, I7 LAw \& ConteMp. Prob. 276 (1952), and citations in Lewis, supra note 55, at ro7I-73, to MAX FarRaND (ED.), The Records of the Federal Convention of I787 (I9II); to The Federalist; and to Jonathan Elitot, Debates on the Federai Constitution (2d ed. 1836). See also Robert Luce, Legislative Principles 359 (I930); L. F. Schmeckebier, Congressional Apportionment (I94I). 
it is a short step to argue that congressional districting within states should likewise be on a straight population basis. More numerous and complicated factors, including area, traditional local unit boundary lines, and bicameralism, enter the picture in regard to an equal protection plea against state legislative districts. ${ }^{82}$

Third, remedies available, including the appropriateness of using an election at large may be quite different. An order to an administrative official may suffice in some state legislative districting cases. ${ }^{83}$ Congressional districting normally involves action by the state legislature.

The superficially appealing possibility of an election at large has far greater appropriateness for congressional elections, where a state voice in Congress is the primary aim. For election of state legislators geographic diffusion which is part of the theory of representation could be jeopardized or terminated by the voting power of one or two urban areas where a majority of the electors reside.

\section{Federal Courts: Apportionment Cases Before Baker v. Carr}

The important starting date ${ }^{84}$ for attempts to involve the Supreme Court in apportionment and districting matters is 1932 . Two-thirds of the states were affected by the congressional reapportionment after the $193^{\circ}$ census. Where the state legislature failed to redistrict in states receiving additional seats in the House of Representatives the election at large device could be used for the additional representation, leaving the previous districts intact for the remaining representatives and thus insuring continued geographic spread of representation throughout the state. ${ }^{85}$ The critical problem was posed by states losing representation. In several of these states after the legislature had redistricted to absorb the loss, suits were filed challenging the new districts. Four of these cases reached the Supreme Court, two from state courts ${ }^{8 \mathrm{~B}}$ and two from federal district courts. ${ }^{87}$ The Supreme Court also received a state court case from a state with increased representation. ${ }^{88}$

The three cases from the state courts turned on the applicability of the governor's veto to a redistricting of congressional districts. As handled by the Supreme Court they did not involve the question of the existence and applicability of overriding federal substantive standards.

The leading case was Smiley $v$. Holm ${ }^{89}$ from Minnesota and its decision con-

${ }^{82}$ Durfec, supra note 74; Fordhax, op. cit. supra note 70, at 27-42; LuCE, op. cit. supra note 81, at 364.

${ }^{83}$ See I96I Oregon litigation, supra note 69; Suffolk County litigation, supra notes 31-34.

st Earlier unsuccessful attempts produced no articulation of principle, e.g., denial of certiorari in one of the Illinois legislative district cases, supra note 25.

${ }^{85}$ Scull, Legislative Apportionment and the Law, 18 T'EMPLE L.Q. 388 (1944); Koenig v. Flynn, 258 N.Y. 292, 179 N.E. 705 (1932), aff'd, 285 U.S. 375 (1932).

${ }^{80}$ Smiley v. Holm, 285 U.S. 355 (1932), reversing I84 Minn. 228, 238 N.W. 494 (1931); Carroll v. Becker, 329 Mo. 50I, 45 S.W.2d 533 (1932), affd, 285 U.S. 380 (I932).

${ }^{87}$ Wood v. Broom, 287 U.S. I (1952), reversing I F. Supp. 134 (S.D. Miss. 1932); Mahan v. Hume, 287 U.S. 575 (1932), reversing I F. Supp. I42 (E.D. Ky. 1932).

${ }^{88}$ Koenig v. Flynn, supra note 85 .

${ }^{80} 285$ U.S. 355 (1932), reversing 184 Minn. 228, 238 N.W. 494 (1931). Minnesota's representation had been reduced from ten to nine. 
trolled the other two, Carroll v. Becker ${ }^{00}$ from Missouri and Koenig v. Flynn ${ }^{21}$ from New York. In Smiley the petitioner sought a declaration of the invalidity of the redistricting statute and an injunction against its use on the grounds, first, that the governor's veto power applied to this matter and that the statute had not been repassed over his veto, and second, that the statute violated the standards of compactness, contiguity, and population equality of the IgrI Federal Reapportionment Act. ${ }^{82}$ The Minnesota Supreme Court, agreeing with the defense of the state attorney general, ordered dismissal. ${ }^{93}$ First, the court held that in this redistricting the legislature was exercising a special federal constitutional power rather than a normal state lawmaking power subject to gubernatorial review and veto. Second, the court held that the Federal Reapportionment Act of rgII with its substantive standards on districting had expired, and said that, even if still in existence, this aspect of the case would present a non-justiciable, political question.

The United States Supreme Court never got to this interesting second aspect of the case. It simply reversed the state court on the first aspect of the case because it found that the federal Constitution did not invest state redistricting with such special character as to shield it from gubernatorial veto. ${ }^{94}$ In a dictum it noted that this result left Minnesota with no valid districts and that absent a timely enactment of a new and valid statute the only recourse would be election at large of Minnesota's congressional delegation. ${ }^{95}$ Similar results, and dicta on the appropriateness of an election at large, followed in Carroll v. Becker ${ }^{96}$ and Koenig v. Flynn.97

The issue left unresolved in Smiley, i.e., the question of the existence and enforceability of the IgII Reapportionment Act's standards against the states, was resolved in appeals from two federal district courts, Wood $v$. Broom $^{98}$ and Mahan v. Hume. ${ }^{98}$ There the Supreme Court ordered dismissal of injunctions which federal district courts had issued against the new state districting statutes for noncompliance with the standards of the IgII Act. The Court concluded the IgII Act had expired.

On the question of justiciability of apportionment suits, these five cases left some questions unanswered. The Smiley opinion contained a cryptic remark suggestive

${ }^{00} 329$ Mo. 501, 45 S.W.2d 533 (I932), aff'd, 285 U.S. 380 (r932). Missouri's representation had been reduced from sixteen to thirteen.

${ }^{21} 258$ N.Y. 292 , 179 N.E. 705 (1932), aff'd, 285 U.S. 375 (1932). New York's representation had been increased from forty-three to forty-five. The legislature had sought to avoid the veto power by the device of concurrent resolution.

${ }^{03}$ Act of Aug. 8, 191r, ch. 5, $\$ 3,37$ Stat. 13.

${ }^{03}$ State v. Holm, 184 Minn. 228, 238 N.W. 494 (193r).

"Smiley v. Holm, supra note 86 .

of Id. at 374 .

${ }^{90} 329$ Mo. 501, 45 S.W.2d 533 (1932), $a f^{\prime} d, 285$ U.S. 380 (1932). The Missouri Supreme Court's dictum concerning an election at large, 45 S.W.2d 535, and quoted by the United States Supreme Court, 285 U.S. 382 , sounds mandatory. However, the only action was to refuse to issue a mandamus to the Secretary of State to order him to receive a filing of a candidacy under the new but vetoed law.

${ }^{97} 258$ N.Y. 292 , I79 N.E. 705 (1932), aff'd, 285 U.S. 375 (1932).

${ }^{98} 287$ U.S. I (1932), reversing I F. Supp. 134 (S.D. Miss. 1932). Mississippi's representation had been reduced from eight to seven.

* 28 7 U.S. 575 (1932), reversing I F. Supp. I42 (E.D. Ky. 1932). Kentucky's representation had been reduced from eleven to nine. 
of the inference that recourse should be had to Congress for state malfunction on congressional districts, and not to the courts, unless Congress specifically directs otherwise. The Court said: "In exercising this power, the Congress may supplement these state regulations or may substitute its own. It may impose additional penalties for the violations of the state laws or provide independent sanctions. It "has a general supervisory power over the whole subject.' "100

Any such inference is severely undercut, however, by the Court's brushing aside of the second plea in Smiley-alleged noncompliance with the standards of the rgrr Act-as not being properly before the Court, in the light of its disposition of the gubernatorial veto issue, and therefore "wholly abstract."101 This suggests the inference that in a proper case the Court would have power to consider the matter, and might consider it appropriate to exercise this power.

These possible conflicting inferences were not resolved in Wood and Mahan. Justice Hughes' opinion of the Court, grounded on the conclusion that the rgrr Act had expired, suggests the inference that if the act had not expired the Court would have considered the question. ${ }^{102}$ But again, such an inference is undercut because four members of the Court-Justices Brandeis, Stone, Roberts, and Cardozo-would have dismissed the suit for "want of equity."103 The "want of equity" phrase suggests a policy of judicial self-limitation analogous to the doctrine of political questions, and probably indistinguishable in this context. It suggests that the Court normally would not exercise jurisdiction in this kind of case, despite noncompliance with either statutory or constitutional standards.

Justiciability is also affected by prospective unavailability of a feasible remedy, an especially important consideration in apportionment suits. Failure to take account of the background of Smiley and the related cases, and of the specific relief requested, has produced erroneous assertions by several commentators that the federal courts had assumed jurisdiction and ordered elections at large. ${ }^{104}$ These assertions create the misleading impression that federal courts, even prior to Baker v. Carr, had actively enforced federal substantive standards against the states in apportionment and districting matters. Actually, the issue in Smiley was whether the new districting statute could be saved by finding, in effect, a federal exemption from the gubernatorial

\footnotetext{
${ }^{200}$ Smiley v. Holm, supra note 86 , at $366-67$.

${ }^{101} \mathrm{Id}$. at 375 .

${ }^{102}$ Wood v. Broom, supra note 87. Mahan v. Hume, supra note 87, was decided per curiam under authority of Wood $v$. Broom.

${ }^{103}$ Wood v. Broom, supra note 87 , at 8 .

${ }^{104}$ E.g., Lewis, supra note 55, at 1087-88; Brief for the United States as amicus curiae on reargument, pp. 52, 54; Baker v. Carr, 369 U.S. I86 (rg62); Commsston on Civit Righrs Report, Voting (vol. I) 123,128 (Ig6r).

One of the few accurate characterizations of Smiley and related cases is that given by Justice Frankfurter in his dissenting opinion in Baker v. Carr, supre note r, at 284-85: "Where, however, state law has made particular federal questions determinative of relations within the structure of state government, not in challenge of it, the Court has resolved such narrow, legally defined questions in proper proceedings. . . . In such instances there is no conflict between state policy and the exercise of federal judicial power. This distinction explains the decisions in Smiley $\nu$. Holm . . Koenig $\nu$. Flynn . . . Carroll $v$. Becker . . . in which the Court released state constitutional provisions prescribing local law-making procedures from misconceived restriction of superior federal requirements."
} 
veto by treating redistricting of congressional districts as a non-legislative function analogous to the role of state legislatures in ratification of federal constitutional amendments. The Minnesota court had so held. If there were no federal exemption, which was the Supreme Court holding, then by the sequence of congressional action killing the old districts and gubernatorial action killing the new districts, rather than by reason of court order, there would be no valid districts available. In this situation an election at large would be the only way to preserve state representation in Congress and could-and did-occur without specific court order. ${ }^{105}$ Indeed, because of the absence of a Supreme Court-directed order for an election at large in Smiley, a possibility existed that a special legislative session could have produced valid districts in time for the election, or that Minnesota would hold no election of congressional representatives, which would have posed a fresh series of problems.

Before considering the next major federal case, Colegrove v. Green, ${ }^{106}$ it would be well to note that potentially there are three positions which the Supreme Court may take in congressional districting cases, rather than two.

First, the Court could say that article one, section four of the Constitution confers a plenary and exclusive power on Congress, and that the Court has no jurisdiction to entertain a suit unless specifically authorized by Congress. Some language in Smiley supports this idea.

Second, the Court could say that any standards Congress lays down by statute in this field, or any standards of fairness and equality found in the fourteenth amendment's due process or equal protection of the laws clauses, are self-executing. This could mean that federal courts would have jurisdiction under the general grant of judicial power, ${ }^{107}$ to entertain an appropriate suit for redress whenever a federal standard found either in a statute or the Constitution is violated. Further, the courts could proceed to exercise this jurisdiction.

Third, the federal courts could say that they have jurisdiction, as just delineated, but could refuse to exercise jurisdiction on grounds of policy. This policy of not exercising jurisdiction could be explained in such terms as "want of equity," or "political question." At bottom it would be a policy of judicial self-restraint derived from the Court's assessment of the proper limits of its role as guardian of public morals in our political system. If the plaintiff's case rested on the fourteenth amendment, or some other constitutional clause, rather than a federal statute, we

${ }^{205} \mathrm{~A}$ state court case resting on state law grounds eventuated in a mandamus which was in effect an order for an election at large of Virginia's congressional delegation in 1932 . Brown v. Saunders, I59 Va. 28, I66 S.E. I05 (1932). The Virginia legislature redistricted after its congressional delegation was reduced from ten to nine but the governor refused to sign the bill. In the ensuing litigation Brown and others sought and obtained a mandamus to compel the Secretary of the Commonwealth to accept their filings as candidates at large. The court based its decision on a Virginia Constitution provision, not generally found in state constitutions, that congressional districts be "composed of contiguous and compact territory, and containing as nearly as practicable an equal number of inhabitants."

${ }^{100} 328$ U.S. 549 (I946).

${ }^{107} 28$ U.S.C. $\$ 1343$ (1958). In so far as the state law was a violation of a federal constitutional standard, REV. STAT. $\$ 1979$ (I875), $42^{\circ}$ U.S.C. $\$$ I983 (1958). 
would be justified in referring to such policy of judicial self-restraint as a constitutional policy regarding the limits of judicial review.

Of all the precedent cases, Colegrove v. Green casts the longest shadow over the Baker v. Carr litigation. Because Colegrove involved congressional districts while Baker involves state legislative districts, there may be some ground to argue, albeit narrow, that the holding of justiciability in Baker does not necessarily overrule Colegrove. In Colegrove a seven-man Supreme Court split 4-3 in dismissing a suit seeking to restrain further use of Illinois' congressional districts on the ground that inequality in population violated the fourteenth amendment. But the court split 3-3-r in its reasoning.

Justice Frankfurter's plurality opinion, in which only two others concurred, is not easy to characterize. It is one of those opinions that says all things to all men, and has even been cited by some lower court judges in support of exercise of jurisdiction where state legislative districts, rather than congressional districts, were at issue. ${ }^{108}$ Justice Frankfurter may have put the dismissal under the first of the three potential positions delineated above--that is, lack of jurisdiction. He relied in part on article one, section four, of the Constitution and Smiley v. Holm ${ }^{100}$ for the proposition that the Court lacked power (i.e., jurisdiction) to proceed, the matter being exclusively committed to Congress. But he also talked about the danger of courts entering the "political thicket"110 which is language more appropriate to position three. There also was language phrased in terms of standing to sue, doctrine of political questions, delicacy of federal-state relations, and unsuitability of the remedy of election at large. As the Solicitor General observed in his brief as amicus curiae in Baker v. Carr, the "relative importance which the three justices joining in this opinion attached to these factors is not clear." 111

Justice Rutledge joined the Frankfurter contingent in the $4-3$ vote to dismiss, but clearly put his vote under position three-there is jurisdiction per se, but for policy reasons it should not be exercised. Justice Black and two others, dissenting, would adopt position two-there is jurisdiction, and it should be exercised.

If the decision in Colegrove really rested on a theory of exclusive commitment of congressional districting matters to Congress, then no later decisions concerning justiciability in federal courts regarding state legislative districts or vote-weighting schemes can affect it. However, if the theory of exclusive commitment to Congress, and the resulting lack of judicial jurisdiction be laid aside, Colegrove becomes a "political question" case. This view is supported by the per curiam opinion in South v. Peters $^{112}$ where the Court dismissed a federal district court challenge to the Georgia

${ }^{108}$ E.g., Magraw v. Donovan, I59 F. Supp. 901 (D. Minn. 1958); Dyer v. Kazuhisa Abe, 138 F. Supp. 220 (D. Hawaï 1956); Latting v. Cordell, 197 Okla. 369, 172 P.2d 397 (1946) (dissenting opinion).

${ }^{109}$ Smiley v. Holm, stipra note 86.

${ }^{110}$ Colegrove v. Green, supre note 106, at 556.

112 Brief for the United States Amicus Curiae, pp. 29-30, Baker v. Carr, 369 U.S. 186 (1962).

${ }^{112} 339$ U.S. 276 (1950). The suit was an attempt to challenge the Georgia county unit system of determining the victor in state-wide primary elections. Under the system victory went to the candidate 
county unit system of weighting votes in favor of rural areas with this statement: "Federal courts consistently refuse to exercise their equity powers in cases posing political issues arising from a state's geographic distribution of electoral strength among its political subdivisions." ${ }^{113}$ This language concedes jurisdiction but finds a policy basis for not acting. Viewed as a political question case, Colegrove is severely undercut by Baker v. Carr and possibly overruled, unless the Court chooses to take a narrow approach when it comes to defining the federal right now being litigated in Baker on remand to the district court. South v. Peters seems clearly overruled. However, because of the complexity and variety of the possible arrangements for apportionment, districting, and vote-weighting, it may be possible to have a continuum of justiciability in this field. ${ }^{114}$

The negative thrust of Colegrove regarding federal court action on apportionment and districting matters was reinforced by a series of per curiam dismissals of federal district court suits. ${ }^{115}$ It was not substantially undercut either by the anomalous opinion in MacDougall v. Green ${ }^{116}$ or Magraw v. Donovan. ${ }^{117}$ The contrary decision in Magraw concerning reapportionment of the Minnesota legislature, which did not reach the Supreme Court, was achieved almost inadvertently. The single judge ${ }^{118}$ with whom the petition was filed denied the motion to dismiss because he found that jurisdiction in the sense of a colorable federal claim was present. His attempt to distinguish the Colegrove and South $v$. Peters precedents was brief to the point of being casual, and he did not distinguish jurisdiction and justiciability. The

who prevailed in the total county unit vote, which was allocated in each county to the candidate with the popular vote plurality in that county. In the basic allocation of "units," the more populous counties were discriminated against. This special, and particularly pernicious, species of the gerrymander, was alleged to violate the fourteenth and seventeenth amendments in regard to equal protection of the laws and right to an equal vote for United States senators. For discussion of the Georgia county unit system prior to the litigation following Baker v. Carr, see Cornelius, The County Unit System of Georgia: Facts and Prospects, 14 Western Pol. Q. 942 (Ig6r).

${ }^{213}$ Id. at 277. (Emphasis added.)

114 A continuum perhaps already exists. Suits about rights of individual voters to be enrolled and reccive a ballot and have it counted fairly are clearly justiciable. It has been argued that these suits differ only in degree and not in kind from legislative apportionment, under one broad heading of "election process." See Justice Douglas, concurring in Baker v. Carr, supra note $x$, at 247-49.

216 Listed stipra note 49.

${ }^{110} 335$ U.S. $28 x$ (I948). The suit involved a federal constitutional challenge to the Illinois law requiring a petition containing at least 200 signatures from each of fifty of the state's one hundred and two counties as a precondition of placing nominees of a new political party on the ballot. The law was an obstacle to activities by the Progressive Party whose nominees for President and Vice President in I948 were Henry Wallace and Glen Taylor. The federal district court in one breath upheld the constitutionality of the law and in the next breath denied it had jurisdiction. 80 F. Supp. 725 (N.D. Ill. 1948). The Supreme Court affirmed but some language in the opinion, as augmented by Justice Rutledge's separate concurrence, led the Solicitor General in his amicus curiae brief in Baker $v$. Carr to say that the Court had passed on the merits. Brief for the United States as amicus curiae on Reargument, pp. 56-57, Baker v. Carr, 369 U.S. 186 ( $\mathrm{Ig62}$ ). However, MacDougall (I) did not involve apportionment but rather a geographic diffusion rule imposed as a condition of getting a new political party on the ballot, (2) may have been decided on justiciability grounds because the Court cited the Colegrove principle, and (3) as Justice Frankfurter has said, "of decisive significance is whether in each situation the ultimate decision has been to intervene or not to intervene." Baker v. Carr, supra at 285.

${ }^{117} 159$ F. Supp. 901 (D. Minn. 1958), 163 F. Supp. 184 (D. Minn. 1958), I77 F. Supp. 803 (D. Minn. I959). Sec text supra at note 63 .

${ }^{118}$ I59 F. Supp. gor (D. Minn. 1958). 
resultant three-judge district court ${ }^{119}$ then proceeded to approach the merits without ever discussing justiciability - that is, the question whether the court should exercise its technical jurisdiction. The justiciability issue thus fell between two stools, and was never meaningfully treated. ${ }^{120}$

The Tuskegee gerrymandering case, Gomillion v. Lightfoot, ${ }_{1}^{121}$ in which the Court voided an Alabama statute which had purported to detach from the town of Tuskegee most of the territory on which Negro voters resided, likewise did not foretell the Baker v. Carr decision. Even conceding that Gomillion would rest more soundly on the equal protection clause, where Justice Whittaker would put it, ${ }^{122}$ than on the fifteenth amendment where Justice Frankfurter's opinion for the Court put it, ${ }^{123}$ it differs from Baker v. Carr in two major respects. First, it involved state action obviously geared to race which has been almost a per se violation of the fourteenth amendment ever since Strauder v. West Virginia. ${ }^{124}$ Second, a ready remedy was available in the form of an injunction to restore the previous boundaries.

\section{E. State of the Law on the Eve of Baker v. Carr}

This review of state court and federal court action on apportionment and districting matters prior to Baker v. Carr yields several generalizations. In addition to the fact that state judiciaries are not bound by the federal separation of powers doctrine and federal precepts of justiciability, there has been a general lack of precise discussion either of issues of standing or justiciability in the state cases. The older breed of rough-and-ready state judges tended to ignore these niceties of advanced jurisprudence. Even where state courts acted, they were weak in formulating remedies and rarely did more than invalidate legislative action, often under relatively

${ }^{110}$ I63 F. Supp. 184 (D. Minn. I958).

${ }^{120}$ Dyer v. Kazuhisa Abc, 138 F. Supp. 220 (D. Hawaii 1956), reversed on other grounds, 256 F.2d 728 (9th Cir. 1955), which also did not reach the Supreme Court, involved a territorial court, not a constitutional court. It was decided specifically on the ground that the issue did not involve federalstate relations, Hawaii still being a territory. See discussion, text supra at note 57 et seq.

${ }^{121} 364$ U.S. 339 (1960). The background and the flavor of the oral argument in the Supreme Court are portrayed in Bernard Taper, Gomillion versus Lightfoot: The Tuskegee Gerrymander Case (1962).

${ }_{122}$ Id, at 349: "But it does seem clear to me that accomplishment of a State's purpose-to use the Court's phrase- of 'fencing Negro citizens out' of Division A and into Division B is an unlawful segregation of races of citizens, in violation of the Equal Protection Clause of the Fourtecnth Amendment ....."

${ }^{123} \mathrm{Id}$. at 346 . Because there was no showing that the Negroes were being deprived of voting in their new "location," it would seem that their basic loss was in being segregated in regard to various benefits of urban life of which voting in city elections was only one facet. An equal protection plea is more responsive to such a situation than a fifteenth amendment plea of a right to vote free from racial restraint. Justice Frankfurter's fifteenth amendment approach was, of course, a way of acting in the Alabama situation while at the same time doing as little violence as possible to the Colegrove precedent.

${ }^{124}$ I00 U.S. 303 ( 1880 ), reversing conviction of Negro defendant by jury on which only whites were eligible to serve. Brown v. Board of Education, 347 U.S. 483 (r954), by rejecting the separate but equal doctrine of Plessy v. Ferguson, I63 U.S. 537 (1896), seems to mark a return to the broad principle of Strauder. The great fallacy of Plessy was to make the constitutionality of official racial segregation turn on reasonableness by analogy to the economic regulation and tax cases where classification was deemed permissible if it had a rational basis. The one clear meaning of the equal protection clause, absolute racial equality before the law, which had not been questioned theretofore, was thus opened to the erosion of plausible exceptions-exceptions perhaps necessary in economic regulation but disastrous to the goals of equality of status of the natural person. 
precise state constitutional standards. In the Ig60 case in New Jersey where a suit successfully impelled legislative action, the state court was never compelled to show its hand. ${ }^{125}$

Federal courts had quite consistently adopted a hands-off attitude, particularly since the Colegrove decision in I946. In the two exceptions in Hawaii ${ }^{126}$ and Minnesota, ${ }^{127}$ the federal district courts, like the New Jersey state court in Ig60, did not have to reach a decision under a broad substantive standard or shape a remedy. Influenced by the Colegrove example, the later state trend seemed to be away from the earlier disposition to assume a "remediless jurisdiction."

No court, federal or state, has ordered an election at large as a remedy for malapportionment of state legislatures. ${ }^{128}$ Election at large of a state's entire congressional delegation has resulted from failure to pass valid redistricting statutes after state apportionments were changed by congressional action. It has not resulted from judicial imposition of substantive federal standards, with one exception in which the standard was statutory; and there the Supreme Court reversed the lower court after the congressional election had been held. ${ }^{129}$ Further, in a precise sense, federal courts have not ordered elections at large..$^{130}$

The major about-face in both federal and state courts impelled by Baker v. Carr is thus not to be minimized by citing an occasional variant straw in the wind. Unlike Brown v. Board of Education, ${ }^{131}$ it was not well signalled by a series of cases in the Supreme Court, or any other courts. What Baker v. Carr represents is an agony of democracy. The Supreme Court, without precedent, finally concluded that some judicial participation in the politics of the people-to a degree as yet undetermined-was a precondition to there being any effective politics.

\section{II}

\section{The Political Setring}

Preparation of charts and tables on rotten boroughs and malapportionment problems has long been an eminently respectable pastime of social scientists even though the effort has normally been more productive of depressing description than productive of effective remedial action. There probably has not been a period in our

${ }^{125}$ Asbury Park Press, v. Woolley, supra note 66.

${ }^{120}$ Dyer v. Kazuhisa Abe, supra note 57 , involved a statutory mandate to reapportion.

${ }^{127}$ Magraw v. Donovan, supra note 63 , involved equal protection but the case was mooted because the legislature acted.

${ }^{288}$ One state court, however, has said such action would be contrary to the state constitution. Kidd v. McCanless, supra note 42; cf. Daly v. County of Madison, 378 Ill. 357, 38 N.E.2d I60 (I94I). See Lewis, supra note 55 , at ro7 I n.82.

${ }^{120}$ Hume v. Mahan, I F. Supp. I42 (E.D. Ky. 1932), rev'd per curiam, 287 U.S. 575 (1932) on authority of Wood v. Broom, 287 U.S. I (1932). See discussion, text supra at note 99 .

${ }^{130}$ The only clear example of judicial action amounting to an order for an election at large seems to be a state case concerning congressional districting and decided under the state constitution. Brown v. Saunders, supra note I05.

${ }^{131} 347$ U.S. 483 (1954), which was foreshadowed by several decisions against racial inequalities in higher education: Sweatt v. Painter, 339 U.S. 629 (1950), which considered intangible as well as tangible inequalities; McLauren v. Oklahoma State Regents, 339 U.S. 637 (1950); Sipuel v. Oklahoma, 332 U.S. 63I (1948); Missouri ex rel. Gaines v. Canada, 305 U.S. 337 (1938). 
history when striking population disparities and gross underrepresentation of particular groups and sections has not existed. ${ }^{132}$ The struggle of Piedmont against Tidewater, of back-country against coastal plain, dates from colonial times, ${ }^{123}$ and has been a more serious problem for democracy than the related question of voting qualifications. ${ }^{134}$

But as wealth has shifted from land to personalty and corporate intangiblesincluding the inherent power of organization itself-the legislatures have come to represent neither people nor wealth, except as the latter could find a shared interest in the rural legislators' lukewarm approach to social welfare and big government. Also, like Eve after the apple, there has been a great change in sensitivity to the population factor in representation formulae. To generations reared in the cult of the ballot the flow of malapportionment statistics has seemed like desecration of the temple of democracy. ${ }^{135}$

More critically, from the standpoint of civic leadership, the newer statistics have shown that the traditional urban-rural split in representation has taken on the new dimension of suburban underrepresentation. ${ }^{136}$ This has seemed to mean that society's best-if education, culture, positions of leadership in the professions and business, and other associations mean anything-were exercising the least direct influence on government.

Against this long-standing and probably worsening problem of underrepresentation of people simply as people, there has been a disheartening chain of failure of attempts at amelioration through usual channels of political action. At the national level, Congress has shown neither disposition nor capacity to police congressional districting through its conceded power of control over its own membership and over

\footnotetext{
${ }^{132}$ See generally: Francis N. Thorpe, Constitumonal History of the AMerican People, 17761850, at 258-59, 43I-55 (1898); id. at 96-129, r83 et seq., 392-435 (1898); Francis N. Thorpe, The Constitutional. History of the UNited States, 1765-I895, at 426 (I901); Robert Luce, Legistative Principles 350-57, 365-68; symposium, Legislative Reapportionment, i7 LAW \& ConteMP. Prod. 253-469 (1952), especially Short, States That Have Not Met Their Constitutional Requirements, id. at 337; Bone, States Attempting to Comply with Reapportionment Requirements, id. at 387 ; Hinderaker \& Waters, $A$ Case Study in Reapportionment-California 1951, id. at 440; Paul T. David \& Ralph Eisengero, Devaluation of the Urban and Suburban Vote (196r); National Municipal League, Compendium on Legislative Apportionment (2d ed. 1962); L. F. SchMectebier, Congressional Apportionment 127-94 (194I); American Politicat Science Ass'n, American State Legislatures 30-46 (Zeller ed. 1954).

${ }_{133}$ Ibid. See also Jackson T. Main, The Antifederalists: Critics of the Constitution, 1781-1788, at $17-24,28$ et seq. ( $\mathrm{rg} 6 \mathrm{I}$ ).

${ }^{134}$ J. Alinn Nevins, The American States During and After the Revolution, 1775-1789, at 95-96, II4-15, 13I-34 (I924). Nevins indicates that malrepresentation, both in terms of area and population, was endemic in the colonial legislatures, and was only partially and gradually ameliorated in the revolutionary and constitution-building era. Property qualifications for voting played their part, but the most striking malrepresentation was in the grossly insufficient number of seats awarded to the growing back country in the Carolinas and Virginia. Also see Robert E. Brown, Middle-Class Democracy and the Revolution in Massachusetrs, I691-I780 (1955); Robert E. Brown, Charles Beard and the Constitumion $6 \mathrm{x}-72$ (1956). In his first work, Brown shows that property qualifications were so low that $\mathrm{few}$ men in Massachusetts were disfranchised. In his second work he draws similar conclusions regarding other states and finds little evidence for Beard's famous thesis that only a tiny electorate ratified the Constitution.

${ }^{\text {Ias }}$ See charts $\mathrm{TV}$ and $\mathrm{V}$ in Appendix.

19e Ibid. Also see Friedman, Reapportionment Myth, 49 Nat. Crvic Rev. 184 (1960).
} 
the seating of persons sent by the states. From the census of 1870 to the census of rgro the federal reapportionment acts required the state legislatures to devise congressional districts of "equal" population and "contiguous" territory, ${ }^{137}$ and after the census of I900 the requirement of "compactness" was added.138 And yet during this period, even though it preceded the big wave of urbanization, there were important disparities of population between districts in many states. That the disparities were not greater than they were is to be attributed not so much to an attempt to abide by the standards as to the fact that urbanization had not reached full flower. ${ }^{139}$

The House of Representatives has never taken unequal representation seriously, although the matter was at least discussed on three occasions: ${ }^{140} I 843$, when four states did not use districts at all; I90I, involving a Kentucky district; and I9ro, involving a Virginia district. Because Congress at any given time is itself the product of a mixed and imperfect apportionment and districting process, to expect Congress to take forceful action on this problem is to expect a stream to rise above its source. Interminable wrangles and interstate reprisals, compounded both by party and sectional alignments, would flow from such action. Proposals for more vigorous congressional action and bills introduced in recent congresses to take a more positive approach have gone unheeded. ${ }^{141}$

In the state legislatures such recent progress as has been made has been due in part to the efforts of the governor, as urban spokesman, ${ }^{142}$ but a glance at the figures in

${ }^{297}$ I7 Stat. 28 (1872); 37 Stat. I3, I4 (I9II).

${ }^{138} 31$ Stat. 733 (190I). These requirements were dropped in 1929. 46 Stat. 21 (1929).

${ }^{130}$ Examples of population disparities between districts under the 1910 census are given in SCHMECREBIER, op. cit. supra note 132 , at $153,154,156,162,172$, I75; e.g., Colorado, largest district 228,444 and smallest district 134,469 ; Connecticut, 250,182 and 190,403 ; Illinois, 349,883 and 167,634 ; Louisiana, 234,382 and 165,563 ; New York, 300,000 and 194,708; Ohio, 264,297 and 164,474. A list covering all the states for the year 1897 is found in appendix I to Justice Frankfurter's opinion in Colegrove v. Green, 328 U.S. $549,557-59$ (1946).

${ }^{140}$ SchMEckebier, op. cit. supra note 132 , at $135-38$. The reasons for rejecting the challenges in the latter two instances, as given in the congressional committee reports, have been summarized as follows: "( $(I)$ Such action would leave the voters in the affected districts without any representation for two years. (2) It would put enforcement of the equality requirement in the hands of the transitory House majority and might lead to politicking on a larger scale with the apportionment problem. (3) Members would be prey to constant uncertainty, not knowing when their seats might become pawns in some party struggle in the House. (4) To enforce equality 'spasmodically' by occasional challenges to seating would be unfair and ineffective; it should be done 'universally' as to all districts." Lewis, supra note 55 , at ro94.

${ }^{161}$ E.g., American Political Science Ass'n, Report of Committee on Reapportionment of Congress, 45 AM. PoL. Scr. REv. 153 (I95I); Hearings Before the Special Subcommittee on Reapportionment of the House Committee on the Judiciary on Establishment of Congressional Districts, 82d Cong., Ist Sess., ser. 21 (195I); Hearings Before Subcommittee No. 3 of the House Committee on the Judiciary on Increasing the Membership of the House of Representatives and Redistricting Congressional Districts, 87th Cong., Ist Sess., ser. 9 (I96I); S.J. Res. I4I, 87th Cong., Ist Sess. (I96I), constitutional amendment proposed by Senator Clark to require substantial equality in population of congressional districts.

A common feature of the bills is to forbid deviation by more than a specified percentage, e.g., $15 \%$, from the average district population of the state, enforced either by Congress through refusal to seat members from improper districts or by a voter suit in federal district court.

${ }^{12}$ Bone, States Attempting to Comply with Reapportionment Requirements, 7 LAw \& Contemp. Prob. 387,4 I $^{-1} 4$ (1952). One of the amicus curiae briefs filed in Baker $v$. Carr was by Oklahoma Governor J. Howard Edmondson. 
a recent survey show that the results have not been striking. ${ }^{143}$ Indeed, malapportionment of state legislatures is far worse than malapportionment of congressional districts. The initiative, available in only a minority of the states, has been quite ineffective. ${ }^{144}$

In short, political avenues of redress have proven to be dead-end streets. Population growth and shift have worsened, rather than lessened, the long-standing problem. Against this background the traditional closing line of the opinions of noninterventionist courts that redress lay through the ballot box and not through the courts-that the cure for the ills of democracy is more democracy-took on an increasingly hollow ring. Effective representation of urban-suburban interests had become a direct function of executive leadership. It may be that this background, more than legal disputation on precedents and problems of remedy, dictated the Baker $v$. Carr decision. The structure of the democratic state itself was at stake, once it be conceded that population merits a prominent place, if not a dominant place, in any representation formula.

\section{III}

\section{Baker v. Carr: The Decision}

The Supreme Court decision in Baker v. Carr ${ }^{145}$ can aptly be described as a threelegged stool, with a crucial fourth leg yet to be constructed. The Court found that federal district courts had jurisdiction of claims that state legislative apportionments are in violation of the fourteenth amendment. It found that the plaintiffs had standing as resident voters to assert such a claim. It held that such claims were justiciable despite previous "political question" precedents. It then remanded without reaching the merits and without giving the district court any guidance on the possible nature or dimensions of a federal restriction on state discretion in apportionments. In sharply delineating these four elements which are present in all cases whether separately considered or not, the Opinion of the Court written by Justice Brennan dispelled the confusion which the district court had created by the intermixture of "jurisdiction" language and "justiciability" language in its dismissal. ${ }^{140}$ Justices Douglas, Clark, and Stewart wrote separate concurrences; Justices Frankfurter and Harlan each wrote a separate dissent.

\section{A. The Complaint and Factual Setting}

Mindful of the "political thicket" precedents the plaintiffs placed some stress on the previous unsuccessful political efforts to impel action under the state constitution's

${ }^{1 * 8}$ See chart $\mathrm{V}$ in Appendix.

144 Bone, supra note 142, at 409-12; Brief of J. Howard Edmondson, Governor of the State of Oklahoma, as Amicus Curiae, pp. $\mathrm{x}_{4}$-r7, Baker v. Carr, 369 U.S. 186 (1962).

${ }_{1405} 369$ U.S. I86 (1952). The previous unsuccessful attempt to achieve redress in the state courts is noted supra at note 42, Kidd v. McCanless, 200 Tenn. 273, 292 S.W.2d 40, appeal dismissed, 352 U.S. 920 (1956). The matter was started again in federal district court in 1959, Baker v. Carr, 175 F. Supp. 649 (M.D. Tenn. I959), argued in the Supreme Court on April 19-20, 196r, set for reargument on Oct. 9, r961, 366 U.S. 907 (196r), and finally decided and remanded on March 26, r962.

${ }^{140}$ Baker v. Carr, I79 F. Supp. 824, 826 (M.D. Tenn. 1959). In dismissing the district court did not attempt to distinguish between the two grounds. 
provision for decennial reapportionments. ${ }^{147}$ The complaint asserted a federal right to numerically equitable apportionment under which the legislative districts, not changed since the state Reapportionment Act of Igor, were allegedly unconstitutional because of gross population disparities. ${ }^{147 a}$ Pending remedial action by the legislature, they sought a declaration of invalidity and an injunction against further use of the Igor Act. They requested a court order directing the defendants (members of the State Board of Elections) to conduct the next legislative elections, both primary and general, at large. They also asserted the appropriateness of a court order decreeing reapportionment by application of the Tennessee constitutional formulae to the latest federal census figures.

Unlike many state constitutions, where apportionment formulae phrased in terms of a population principle are engulfed by exceptions designed to achieve geographic diffusion of political power, ${ }^{148}$ the Tennessee Constitution's apportionment formula puts few qualifications on its basic rule of numerical equality for both houses of the legislature. The basic formula for each house is apportionment "among the several counties or districts, according to the number of qualified voters in each."149 Despite this apparent embrace of the one-man-one-vote principle, population disparities among Tennessee legislative districts ${ }^{150}$ presented the same sorry picture as in most other states. Counties having but thirty-seven per cent of the population elected twenty of the thirty-three members of the state senate. Senatorial district population varied from $\mathrm{r}_{3} \mathrm{I}, 97 \mathrm{r}$ to $25, \mathrm{rg}$. Counties having but forty per cent of the population elected sixty-three of the ninety-nine members of the lower house. The number of voters in the representative districts varied from 42,298 to 2,340 .

Political pressures and the abortive state court suit in $195^{6^{151}}$ had alike proven ineffective either to impel the legislature to act or to accomplish reapportionment directly by constitutional amendment. ${ }^{152}$ Tennessee has no provision for popular initiative. The legislature had not acted, nor could it be expected to act, either to submit constitutional amendments on reapportionment to popular vote or to include reapportionment in the call for a constitutional convention. As Judge Miller had said in deciding that the complaint presented a case for a three-judge district court, "if there is no judicial remedy there would appear to be no practical remedy at all."163

${ }^{147}$ Record, pp. 14-16, 32-38, $126-x 60$ (documented Survey of Legislative Apportionment in Tennessee, I870-1957), Baker v. Carr, 369 U.S. 186 (1962); Brief for Appellants, pp. I4-I5, Baker v. Carr, ibid.

${ }_{1672}$ Plaintiffs also alleged discrimination by the Tennessee legislature against underrepresented counties and in favor of the overrepresented in the collection and distribution of various taxes and tax revenues, notably in the distribution of school and highway-improvement funds. The Court's disposition of the case made specific treatment of these allegations unnecessary, but Justice Frankfurter excepted from his general dissent the question whether such discriminations would violate the equal protection clause if the tax statutes were challenged in a proper proceeding. Baker v. Carr supra note 145, at 298.

According to Brief for Appellants, pp. 5-12, in "round figures, statewide, a $1 / 3$ minority of voters from predominantly sparsely populated counties, select a $\% / 3$ majority of both houses."

${ }_{118}^{18}$ See chart III in Appendix. $\quad{ }_{149}^{14}$ TENN. Const. art. 2, $\$ 5,6$.

${ }^{150}$ Record, supra note 147 , at 25-3I. $\quad 251$ Kidd v. McCanless, supra note 145.

${ }^{102}$ Record, supra note I47; Brief of Appellants, supra note 147.

${ }^{163}$ Baker v. Carr, 175 F. Supp. 649, 652 (M.D. Tenn. I959). 


\section{B. Jurisdiction}

On the question of jurisdiction it was sufficient for Justice Brennan that "the matter set forth in the complaint does arise under the Constitution and is within 28 U.S.C. sec. $1343, " 154$ vesting original jurisdiction of certain federal civil rights claims in United States district courts. In short, a bare allegation of violation of the fourteenth amendment surmounts the jurisdictional hurdle unless the claim is "so attenuated and unsubstantial as to be absolutely devoid of merit,"155 or is "frivolous."156 Jurisdiction involves simply the power to look, without prejudging the final outcome. As the Court had earlier said in Bell v. Hood: ${ }^{157}$

Whether the complaint states a cause of action on which relief could be granted is a question of law and just as issues of fact it must be decided after and not before the court has assumed jurisdiction over the controversy. If the court does later exercise its jurisdiction to determine that the allegations in the complaint do not state a ground for relief, then dismissal of the case would be on the merits, not for want of jurisdiction.

Justice Harlan, dissenting, took issue with his colleagues on this threshold question. He argued that until it first be decided that the fourteenth amendment does impose some restraint on apportionments of state legislatures there cannot even be a colorable federal claim and hence no jurisdiction in a federal court. ${ }^{158}$ Justice Harlan's argument has plausibility if one bears in mind that in previous Supreme Court cases there had not been the slightest intimation that the fourteenth amendment had this meaning. This fact sets the case apart from Bell v. Hood and others relied on by the majority where the alleged federal standard was more familiar and precise. But it really is a sort of chicken-and-egg argument.

If one also bears in mind that the Constitution is a dynamic document, capable of taking on fresh meaning in new situations, it is obvious that from time to time claims will be asserted which will not even be colorable federal claims until after the Court adds the fresh, unprecedented meaning to the Constitution by accepting and deciding the case. Should this process of constitutional development and refinement take place at the "jurisdictional" level, as Justice Harlan apparently would have it, or at the level of trial on the "merits" as the Court would have it? Since an issue of novel constitutional construction should not be decided in any event until after the fullest possible presentation of fact and legal argument, the tidier approach would seem to be that of the Court. Otherwise there would be something like a pre-jurisdictional full trial of the essence of the case.

Consistency would also dictate that dismissal for failure to state a proper federal cause of action should also be characterized as an exercise, not a denial, of jurisdiction. ${ }^{159}$ The Court would be truncating the hearing, not denying power. And the

${ }^{154}$ Baker v. Carr, supra note 145 , at 199.

${ }^{155}$ Ibid., quoting Newburyport Water Co. v. Newburyport, 193 U.S. 56x, 579 (1904).

${ }^{15 s}$ Ibid., quoting Bell v. Hood, 327 U.S. 678,683 (I946).

167327 U.S. 678,682 (1946).

${ }^{158}$ Baker v. Carr, supra note 145, at 33I. Justice Frankfurter did not join Justice Harlan on this point. Id. at 330 .

${ }^{189}$ Bell v. Hood, 327 U.S. $678,682,683$ (1946). 
dismissal would to some extent clarify the dimension of "federal rights." Negative action, as well as affirmative action, can have high didactic value.

\section{Standing}

Perhaps the only simple aspect of the Baker case was the question of plaintiffs' standing to litigate the alleged unconstitutionality of Tennessee's legislative districts under the equal protection clause. As Professor Louis L. Jaffe has noted recently, a direct interference with a citizen's franchise has been actionable as a private wrong since $1703 .{ }^{160}$ And going beyond personalized wrongs, courts "have intervened at the suit of the citizen-voter to enforce a considerable part of the constitutional and statutory code governing the election process."161 Smiley v. Holm and the other "I932 cases"162 cited by Justice Brennan in his Opinion of the Court ${ }^{163}$ are appropriate and indistinguishable precedents on the standing issue, even if inappropriate on the justiciability issue. Under the assumption-which is a necessary assumption for the purpose of determining standing-that Tennessee's districts produce a federally cognizable injury, the Baker plaintiffs are among those who have sustained it.

The only troublesome prior Supreme Court language on the standing issue was the comment in Justice Frankfurter's plurality opinion in Colegrove v. Green in which he said, inter alia, that the "basis for the suit is not a private wrong, but a wrong suffered by Illinois as a polity."164 However, the force of this language was undercut within the Colegrove opinion itself because Justice Frankfurter also discussed justiciability, which logically would not have to be reached if there were no plaintiffs entitled to address the Court. It also was undercut either directly or sub silentio in subsequent cases where the Court passed beyond standing to discuss either justiciability or the merits. ${ }^{165}$ In his dissent in Baker Justice Frankfurter did not repeat this language; nor did the other dissenter, Justice Harlan, discuss standing.

The Court's decision and remand in Baker did leave unresolved certain questions regarding the sufficiency of the parties, particularly whether the county election commissioners were indispensable parties, and if so whether they were reached by naming among the defendants the state Board of Elections as their representative. ${ }^{108}$

${ }^{200} \mathrm{Jaffe}$, Standing to Secure Judicial Review: Public Actions, 74 HArv. L. Rev. 1265, 1297 (I96I), citing Ashby v. White, 2 Ld. Raym. 938, 92 Eng. Rep. I26 (Q.B. I703).

${ }^{102}$ Ibid.

102 See discussion of Smiley and related 1932 cases in text supra at notes 89 et seq.

${ }^{103}$ Baker v. Carr, supra note 145, at 206-08. ${ }^{104}$ Colegrove v. Green, supra note 106, at 552.

${ }^{185}$ E.g., MacDougall v. Green, supra note II6; South v. Peters, supra note II2.

${ }^{100}$ The complaint had named as defendants the Tennessee Secretary of State, the Attorney General, the Coordinator of Elections, and the members of the State Board of Elections. The Board members were sued in their own right and also as representatives of the County Election Commissioners whom they appoint.

On the other side of the case the Court had no trouble with the status of the initial plaintiffs, voterresidents in underrepresented districts, who sued on their own behalf and; on behalf of all qualified voters of their respective counties and all Tennessee voters similarly situated. The additional averment that these plaintiffs were suing "on behalf of all other voters in the State" caused Justice Brennan to wonder whether plaintiffs were also asserting that voters in counties allegedly overrepresented also have standing to complain. However, he deemed it unnecessary to resolve this question. Baker v. Carr, supra note I45, at 205 n. 24 .

The Court also left unresolved the question whether the Mayor of Nashville and the cities of 


\section{Justiciability}

Yes!

There is a temptation to let this heading go with that one word. If there is some merit in Justice Clark's flip observation that Justice Frankfurter's words "go through so much and conclude with so little,"167 there would be about equivalent merit in an observation that the majority's words "go through so little and conclude with so much."

Whether one agrees with or differs from Justice Frankfurter's negative conclusion on justiciability-and the writer feels that he must disagree-Justice Frankfurter's lengthy opinion, in this landmark case not marked by equally landmark opinions, bears out his accolade of "scholar on the bench."168

The general approach of the full opinions on the majority side-Justice Brennan for the Court, Justice Douglas, and Justice Clark ${ }^{169}$-was to distinguish and explain away the apparent contrary decisions or dicta of the past rather than to overrule them. In the process they succeeded mainly in further muddying the already murky waters of precedent. If the past was really so inconclusive and uncontrolling of the issue in Baker v. Carr, then a great many commentators, lawyers and laymen alike, had been led into needless worry and idle speculation. Wholly lacking from Baker is the stark simplicity, and brevity, of Chief Justice Warren's statement in Brown v. Board of Education that "We cannot turn the clock back . . . we must consider public education in the light of its full development and its present place in American life throughout the Nation."170 The lack of articulation in Baker of a "necessitychanging times" principle is all the more surprising in view of the major reversal of very recent precedent which the decision represents.

(I) Justice Brennan. The tone of Justice Brennan's section on justiciability is set in his first paragraph where he not only states that apportionment presents no nonjusticiable political questions but also asserts that "cited cases do not hold the contrary."171 The district court had "misinterpreted" the decisions of the Supreme Court, including Colegrove, on which it relied.

He proceeded to analyze the political question doctrine under several headings: past development of it in cases on matters other than voting and elections; its relation to and partial derivation from the separation of powers doctrine; its essence, stated as a matter of affirmative definition. ${ }^{172} \mathrm{He}$ then devoted several pages to a

Chattanooga and Knoxville-permitted to intervene as parties plaintiff-had standing to sue as representatives of the residents of their respective jurisdictions. They pressed the same claims as the initial plaintifs. Id. at 204 n. 23 .

${ }^{107}$ Baker v. Carr, supra note I45, at 25I.

${ }^{168}$ Helen S. Thomas, Feitx Frankfurter, Scholar on the Bench (1960).

${ }^{100}$ Justice Stewart contributed a cautionary note, not a full opinion.

170347 U.S. $483,492-93$ (1954). ${ }^{172}$ Baker v. Carr, supra note 145 , at 209.

173 His summary of the elements of the political question category omits one crucial item-prospective lack of an effective and enforceable remedy. He views the political question doctrine as "essentially a function of the separation of powers." Elements include a "constitutional commitment of the issue to a coordinate political department; or a lack of judicially discoverable and manageable standards for resolving it; or the impossibility of deciding without an initial policy determination of a kind clearly for non- 
refutation of the argument that the Tennessee apportionment case was analogous to the line of cases under the guarantee clause ("republican form of government") which traditionally had been classified-and properly, he would admit-as presenting "political questions." It would have been helpful if he had devoted an equal amount of space to an explicit analysis of the reasons why apportionment cases should not likewise be classified as political questions even though they fall outside the guarantee clause area, which after all is only a political question subheading.

Coming to the case at hand he gave hurried treatment to the prior federal precedents relied on by the district court, in the course of which he mis-characterized Smiley $v$. Holm $^{174}$ and the other 1932 cases as having "settled the issue in favor of justiciability of questions of congressional redistricting."175 Actually, as noted earlier, these cases only "settled the issue in favor of justiciability" of one type of question concerning congressional redistricting, and a very narrow one at that. They concerned the applicability of the governor's veto power to a state redistricting statute and did not raise at all the question of a substantive federal restraint on state weighting of voting strength among counties or districts. ${ }^{176}$

Justice Brennan then concluded in favor of justiciability without ever reaching the factors of vagueness regarding the possible federal standard and of dubiety regarding possible remedies. ${ }^{177}$ And yet these factors, more than abstractions about separation of powers, provide much of the impetus for a political question classification. By remaining at a high level of abstraction in his discussion of "jurisdiction" and in his discussion of "justiciability" he bypassed two opportunities for careful, preliminary speculations concerning possibilities for solution of the critical standardremedy problem.

This is not to say that standards cannot be devised and remedies applied. It is to suggest that the Court seems to have decided justiciability in such a generalized context as to amount to judicial adventuring on the high seas of politics with no assurance of a safe return to shore. One cannot help but feel that it was this lack of a searching analysis of the possibilities regarding the federal standard and federal remedies, as much as the actual decision, that upset Justices Frankfurter and Harlan.

\footnotetext{
judicial discretion, or the impossibility of a court's undertaking independent resolution without expressing lack of the respect due coordinate branches of government; or an unusual need for unquestioning adherence to a political decision already made; or the potentiality of embarrassment from multifarious pronouncements by various departments on one question." Baker v. Carr, supra note 145, at 217.

${ }^{173}$ U.S. ConsT. art. IV, $\$$ 4. Justice Brennan's handling of the guarantee clause precedents has been questioned in Bonfield, Baker v. Carr: New Light on the Constitutional Guarantee of Republican Government, 50 CAIIF. L. REv. 245, 252 (I962): "Nevertheless, the net conclusion of his opinion seems to be that the issue presented in Baker $v$. Carr is justiciable when presented under the equal protection clause, but nonjusticiable when raised under the guarantee. This seems rather incongruous."

174285 U.S. 355 (1932).

${ }^{170}$ See discussion in text supra at notes 89 et seq.

${ }^{177} \mathrm{He}$ did make one off-hand assertion that "judicial standards under the Equal Protection Clause are well developed and familiar. ..." Baker v. Carr, supra note 145 , at 226. Actually, apart from race, the content of the equal protection clause has been uncertain and appeal to it has often been unsuccessful as indicated in Justice Holmes' reference to it as a "last refuge of constitutional argument." See generally Robert J. Harris, The Quest for Equality (rg60).
} 
(2) Justice Douglas. Justice Douglas already had spoken on the basic issue, ${ }^{178}$ and he hewed to his previous line. He made now no pretense of arguing that the present majority result was what the Court had intended all along, except for a cryptic footnote endorsing in general Justice Brennan's historical review. ${ }^{170}$ The main thrust of his opinion was to document the idea that in numerous cases in the past federal courts have intervened to safeguard the voting rights ${ }^{180}$ of individuals against violence at the polls, ${ }^{181}$ discrimination on racial grounds, ${ }^{182}$ or slippery election practices. ${ }^{183}$ With these past cases few persons would disagree, and certainly not Justice Frankfurter or Justice Harlan. ${ }^{184}$ But these precedents concerning judicial action on particularized pleas of individual voters would seem to have little or no relevance concerning weighting, through apportionment, of votes freely cast and counted, unless an emotive righteousness, rather than reason, is to become the touchstone of judicial action. ${ }^{185}$

(3) Justice Clark. Justice Clark was the only majority Justice who tried to come to grips with the standard-remedy problem, on which ultimately political question issues should turn, rather than on Justice Brennan's separation of powers abstractions. On the justiciability issue itself he was content to rely largely on MacDougall $v$. Green. ${ }^{186}$ Reading it for all it was worth, and perhaps quite a bit more, he concluded that the Court there had adjudicated an equal protection attack on the Illinois election statute. The vagaries of the opinion in MacDougall, the fact that the Court left the Illinois practice undisturbed, and the fact that the law involved conditions for forming a new political party, not apportionment, did not disturb him.

On the question of what would flow from a holding of justiciability in Baker, Justice Clark, like Justice Frankfurter, was unimpressed by the point so stressed in the briefs and alluded to by Justice Douglas that a mere assertion of justiciability very likely would cow the legislature and produce the desired reapportionment, so that a federal standard would never have to be articulated or remedy devised. Because the standard-remedy question replaces justiciability as the current issue, now that

\footnotetext{
${ }^{178}$ E.g., his dissenting notes or opinions in Colegrove v. Green, 328 U.S. 549 (1946); Colegrove v. Barrett, 330 U.S. 804 (1947); MacDougall v. Green, 335 U.S. $28 \mathrm{I}$ (1948); South v. Peters, 339 U.S. 276 (1950).

178 Baker v. Carr, supra note 145 , at 241 n.I.

${ }^{280} \mathrm{He}$ constructs and documents this faulty syllogism: many claims about voting by individuals have been treated as justiciable; this apportionment claim has some relation to voting; therefore this suit is justiciable. His major premise is not a "universal," and the class identified in the minor premise is not clearly the same as the class covered by the major premise.

${ }^{181}$ Ex parke Yarbrough, i 10 U.S. 65I (1884).

${ }^{189}$ E.g., Smith v. Allwright, 32I U.S. 649 (1944), and other "white primary" cases.

${ }^{188}$ E.g., United States v. Classic, 313 U.S. 299 (I94I).

${ }^{284}$ Justice Frankfurter voted with the majority in both Smith v. Allwright, stipra note 182 , and United States v. Classic, sutpra note $x 83$.

${ }^{285}$ For an exposition of the Brandeis concern for facts, in the context of the contrasting modes of operation of Justice Black-another judicial "liberal"-and Justice Frankfurter, see Warcace Mrndenson, Justices Black and Frankfurter: Conflict in the Court (ig6r).

${ }^{280} 335$ U.S. 28 I (1948), discussed supra note II6.
} 
Baker has been decided, Justice Clark's detailed observations on it will be reserved for separate treatment below.

(4) Justice Stewart. Justice Stewart did not write a full opinion. He did feel moved to write a brief cautionary note on what the Court had done, and left undone, which would have been a helpful prefix to the opinion of the Court. He wanted to make it clear that in bringing forth its roaring mouse of justiciability the Court had left a little mountain of uncertainty on the merits and the remedy.

(5) Justice Frankfurter. It was to be expected that the "scholar on the bench" would produce an exhaustive analysis commensurate with the landmark dimensions of the case. He gave full measure. He did not deign to analyze the cavils and quiddities by which counsel had sought to distinguish some of the precedent cases. But he felt that no amount of paralogy would serve to distinguish Colegrove v. Barrett, ${ }^{187}$ the challenge in federal district court to Illinois state legislature districts which was on "all fours" with Baker, or Kidd v.McCanless, ${ }^{188}$ which was a "precisely similar attack" to the Tennessee state legislative districts started in state court. ${ }^{189}$ He then embarked on a review of the general nature of "political questions," as revealed in American judicial history over several decades.

In professorial manner he chided those who fail to note "the danger of conceptions of 'justiciability' derived from talk and not from the effective decision in a case."100 He found that judicial use of the "political question" label, as a ground for non-intervention, had been the product of several converging considerations: a spirit of caution where "standards meet for judicial judgment" are lacking; reluctance to "interfere with matters of state government" unless an unquestionable constitutional mandate such as the one against racial discrimination is present; unwillingness to make courts "arbiters of the broad issues of political organization historically committed to other institutions and for whose adjustment the judicial process is illadapted."101 All of these considerations explained the consistent line of decisions holding nonjusticiable claims based on the guarantee clause. ${ }^{192}$

For example, in Luther v. Borden, ${ }^{193}$ in addition to concern over the delicacy of judicial intervention into the very structure of government, the absence of guiding standards for judgment was critical: "... the question whether the Dorr constitution had been rightfully adopted depended, in part, upon the extent of the franchise to be recognized-the very point of contention over which rebellion had been fought."194

The relevance of this background to the case before him was that Baker involved all of the elements that make guarantee clause cases nonjusticiable. In effect, Baker is " $\mathrm{a}$ guarantee clause claim masquerading under a different label."195 And, he

${ }^{287} 330$ U.S. 804 (1948).

280 Baker v. Carr, supra note 145 , at 280 .

${ }^{188} 352$ U.S. 920 (1956).

${ }^{100}$ E.g., Smiley v. Holm and related cases, supra notes 89 et seq., particularly note 104.

${ }^{10 x}$ Baker v. Carr, supra note 145 , at 289 .

${ }^{103} 48$ U.S. (7 How.) I (I849).

192 U.S. CoNST. art. IV, $\$ 4$.

104 Baker v. Carr, supra 145, at 295.

${ }^{105}$ Id. at 297. Bonfield, supra note 173 , expressing the contrary view, seems to place undue weight on 
insisted, the fact that the equal protection label was used did not strengthen one whit the case for justiciability.

The equal protection label fails to help despite the fact that at first blush a charge of discrimination gives "the appearance of more private, less impersonal claim, than the assertion that the frame of government is askew."106 The reason is that the resolution of an equal protection challenge to legislative apportionment ultimately and unavoidably involves a choice among competing theories of political philosophy.

What, then, is this question of legislative apportionment? Appellants invoke the right to vote and to have their votes counted. But they are permitted to vote and their votes are counted. They go to the polls, they cast their ballots, they send their representatives to the state councils. Their complaint is simply that the representatives are not sufficiently numerous or powerful-in short, that Tennessee has adopted a basis of representation with which they are dissatisfied. Talk of "debasement" or "dilution" is circular talk. One cannot speak of "debasement" or "dilution" of the value of a vote until there is first defined a standard of reference as to what a vote should be worth. What is actually asked of the Court in this case is to choose among competing bases of representation-ultimately, really, among competing theories of political philosophy-in order to establish an appropriate frame of government for the State of Tennessee and thereby for all the States of the Union. ${ }^{197}$

Justice Frankfurter then proceeded to place the claim in the perspective of history by surveying the actual practices in regard to legislative apportionment and districting in Great Britain, the colonies, the states at the time of the formation of the Constitution, the states during the nineteenth century including apportionment practices at the time of ratification of the fourteenth amendment, and the contemporary scene. The thought that emerges from this twenty-page survey is that although concern has often been expressed over apportionments grossly malproportioned to population, the generally prevailing feature-if any one feature can be singled out from the numerous widely varying principles and practices-"is geographic inequality in relation to the population standard."108

Justice Frankfurter then concluded his sixty-three page dissent by brushing aside the argument that the federal courts could ease the problem of lack of an adequate guiding standard-and thus ease one worry about results of a finding of justiciability -by simply putting the force of the fourteenth amendment behind the apportionment formulae specified in the Tennessee State Constitution. For, as the Court had said much earlier: "Settled state practice ... can establish what is state law.... Deeply embedded traditional ways of carrying out state policy, such as those of which petitioner complains, are often tougher and truer law than the dead words of the written text."198 From the standpoint of a federal constitutional plea in Baker,

the distinction between those schemes of "malapportionment" which are sanctioned by state law and those-as in Baker-which are contrary to state law. He classifies the former as being within the guarantee clause, the latter as being outside the clause.

${ }^{190} \mathrm{Id}$. at 298-99. ${ }^{107} \mathrm{Id}$. at 299-300. ${ }^{208}$ Id. at 321.

${ }^{100}$ Id. at 326 , quoting from Nashville, C. \& St. L. R. Co. v. Browning, 3 ro U.S. 362,369 (1940). For Justice Harlan also this argument based on the Tennessee Constitution was "manifestly untenable." Id. at 332 . 
the "law" of Tennessee is the actual practice of the past sixty years, not the longignored formal commands of the Tennessee Constitution. So the question remains, given the clear and easily proven "law-practice" of Tennessee regarding reapportionment, does it violate any federal standard?

(6) Justice Harlan. Justice Harlan concurred in Justice Frankfurter's exhaustive treatment of the justiciability issue and in turn was joined by Justice Frankfurter in his separate dissenting opinion. The separate Harlan opinion, like the opinion of Justice Clark on the majority side, was devoted primarily to the standard-remedy question, except for Justice Harlan's opening caveat on the "jurisdiction" issue already discussed.

It was quite clear to him that the equal protection clause did not require that "each vote cast in state legislative elections be given approximately equal weight.",200 Short of that, he was satisfied, too, that the Tennessee apportionment did not offend equal protection by being "so unreasonable as to amount to an arbitrary and capricious act of classification."201 $\mathrm{He}$ also put his finger on what emerges ever more clearly as the nub of the matter, the more one reads the opinions in Baker. The underlying and largely unexpressed premise of the majority and concurring opinions was a sort of necessity principle: ${ }^{202}$

The fact that the appellants have been unable to obtain political redress of their asserted grievances appears to be regarded as a matter which should lead the Court to stretch to find some basis for judicial intervention. While the Equal Protection Clause is invoked, the opinion for the Court notably eschews explaining how, consonant with past decisions, the undisputed facts in this case can be considered to show a violation of that constitutional provision.

Although Justice Harlan's remarks were placed in the context of reinforcing the conclusion of nonjusticiability by showing the great difficulty of relating the equal protection clause to legislative apportionment, his opinion also approached the merits. It amounted to a holding that on facts like those alleged in the Baker complaint and supporting exhibits no violation of equal protection could be shown. To this major and unresolved question of a federal standard for state legislative apportionment, and the related problem of possible remedies, it is now time to turn.

\section{IV}

Is There a Federal Constitutional Standard of Fair Representation?

It is apparent that the express congressional power of apportionment of the House of Representatives, as augmented by the power of each house to control its own membership, would support a broad congressional power to review state practices in regard to formation of congressional districts. ${ }^{203}$ That Congress has not chosen to

${ }^{200} \mathrm{Ibid}$. ${ }^{201}$ Ibid. ${ }^{202} 1 d$, at 339 .

${ }^{308}$ U.S. CoNsr. art. I, $\$ \$ 2,5$. Regarding congressional inaction, in practice, see text supra at notes' $140-4 \mathrm{I}$. 
be active in this field, and that neither the Congress nor the courts enforced such statutory districting standards as did exist in the past, is a matter of history.

In regard to apportionment and districting of state legislatures some congressional power conceivably may derive from the authority of Congress to implement the fourteenth and fifteenth amendments, but it has not been asserted. ${ }^{204}$ Hence, the primary bases for federal challenge to substantive aspects of state apportionment and districting of state legislatures-or state arrangements of congressional districtshave been those constitutional commands which are self-executing, i,e., judicially enforceable without need for implementing statutes. The two leading candidates for the honor of supporting judicial intervention have been the due process and equal protection clauses of the fourteenth amendment, particularly the latter which underlies Baker v. Carr. ${ }^{205}$

\section{A. Judicial History of Equal Protection}

Once the precedents concerning application of the equal protection clause to statesupported or state-permitted racial discrimination are laid aside-and Baker v. Carr is not a race discrimination case-the meaning of equal protection becomes quite elusive. ${ }^{208}$ Justice Holmes, with an aptness not wholly out of date today, has characterized the clause as "the usual last resort of constitutional arguments."207

Non-racial applications of the equal protection clause, as identified in a recent work by Professor Robert Harris, ${ }^{208}$ can be grouped under five major headings: ( $\mathrm{r}$ ) as a barrier to state economic legislation, i.e., regulation or taxation; (2) as a restraint on legislative discriminations in favor of or against women; (3) as a restraint on certain political processes including alleged malapportionment; (4) as a device to mitigate the handicap of poverty in appealing criminal convictions; and (5) some miscellaneous matters of no general import. Baker v. Carr, when finally resolved, may invigorate the "political processes" category in this list. As to the others, with

204 The route of federal constitutional amendment, to assure equitable representation in state legislatures, was suggested by Senator Clark of Pennsylvania in 1960. S.J. Res. 2x5, 86th Cong., 2d Sess. (I960); I06 CoNG. REC. I490I (I960). Because state legislatures themselves are involved in the federal amending process, either by directly ratifying or by setting up ratifying conventions, the proposal obviously was made more for political effect than in expectation of accomplishment.

${ }^{205}$ See discussion of carlier cases, text stpra notes $39 \mathrm{et} \mathrm{seq}$. and ro6 et seq.

200 The "central core of the equal protection clause [is] its application to discrimination based on race or color and the power of Congress and the federal courts to condemn them." RoBErt J. Hurris, The Quest For EQuality 82 (1960).

Racial applications of the equal protection clause become obscure at the frontier of the "state action" concept. 'In deciding whether certain nominally 'private' arrangements have such an effect as to be within the interdiction of the fourteenth amendment, the basic question is the degree of the adverse effect on racial equality of opporrunity rather than 'state action' per se. State action at least of a technical sort is almost ever-present. These border-line determinations will require a more refined concept of equality itself, in the context of the needs of a free and open society. The frontier of equal protection [in race cases] lies in such areas as the Girard Trust case in regard to discriminatory provisions in charitable trusts, in quasi-private publicly-assisted housing, and in quasi-private government contract employment." Dixon, Book Review, 29 Geo. WAsk. L. Rev. 817, 823, (I96I).

${ }_{207}$ Buck v. Bell 274 U.S. 200, 208 (1927).

${ }^{208}$ Harris, op. cit. supra note 206, ch. 3 generally. 
the exception of criminal appeals under the Griffin doctrine, ${ }^{209}$ the reaction of the Court to those who have invoked the clause has been mixed or negative.

Three of these five categories, the economic legislation category-which produced three-fourths of the cases, ${ }^{210}$ the criminal appeals category, and the political processes category, contain possibly significant sources for enlightenment in handling the equal protection plea in Baker $v$. Carr. The remaining two categories principally provide small cases, often mixed with humor. It has always been difficult for the law to take seriously the claims of women for equality. There was a fifty year gap, which some might dub a cultural lag, between the fifteenth amendment and the nineteenth amendment regarding voting by Negro men, and by women, respectively. Among judges, as revealed by the case law, Professor Harris finds "an almost josephic aversion to women." 211 In a relatively recent pronouncement sustaining a Michigan statute forbidding licensing of female bartenders, but containing an exception in favor of the wife or daughter of the male bar owner, Justice Frankfurter recalled "the alewife, sprightly and ribald, in Shakespeare,"212 and said:213

The fact that women now have achieved virtues that men have long claimed as their prerogatives and now indulge in vices that men have long practiced, does not preclude the states from drawing a sharp line between the sexes, certainly in such matters as the regulation of the liquor traffic.

(1) Criminal Pauper Appeals. The rules regarding criminal pauper appeals developed since 1956 represent one of the newer frontiers of the law. But it is not clear whether the rules are properly classifiable as a frontier of equal protection, as the Court seems to have done, or as a frontier of due process, which Justice Harlan in his dissent to the leading case, Griffin v. Illinois, ${ }^{214}$ would have thought more logical. In Griffin the Court reversed, 5-4, an Illinois conviction of two armed robbers who had been unable to appeal because they lacked money for a trial transcript and could not qualify under two free transcript provisos. ${ }^{215}$

Of course, the components of the alleged inequity are quite different in the Griffin line of cases and in legislative apportionment. Apportionment involves

${ }^{200}$ Griffin v. Illinois, 351 U.S. I2 (I956); see text infra notes $2 I_{4}$ et seq.

${ }^{210}$ In terms of numbers, Professor Harris found that of 554 decisions of the Supreme Court in which the equal protection clause had been invoked, three-fourths dealt with economic interests, i.e., state regulation and taxation, and only fifteen per cent dealt with racial discrimination. That non-racial cases have made up the bulk of litigation under the equal protection clause, at least in terms of numbers of cases, illustrates once again how a legal rule developed for one problem will be utilized in a major way in an unintended, or at least unexpected, field. HARRIs, op. cit. supra note 206, at 59 .

${ }^{211} \mathrm{Id}$. at 73 .

${ }^{219}$ Goesaert v. Cleary, 335 U.S. 464,465 (1948).

$213 \mathrm{Id}$. at 466 .

214351 U.S. 12,36 ( 1956$)$.

${ }^{315}$ Both the opinion of the Court by Justice Black and the concurring opinion of Justice Frankfurter seemed to rest essentially on the apparent disparity, in the operation of the state rule, between those who could afford an appeal and those who could not.

Jutice Frankfurter was the more explicit of the two in noting that the Constitution forbids "differentiations by a state that have no relation to a rational policy of criminal appeal." Id. at 22 . This is equal protection language. But he also went on to say that the Constitution forbids "the imposition of conditions that offend the deepest presuppositions of our society." Ibid. This is due process language, implying an absolute restraint on governmental power rather than one keyed to differential treatment. 
alleged state-created inequities in weighting of votes. Criminal pauper appeals turn on the question of the extent to which states are under an affirmative obligation to shape their rules so as to minimize the effect of such natural differences as relative wealth. Griffin conveys the idea that states are under a constitutional duty to insure that poverty-which is not itself a state-created differentiating condition-does not nevertheless, in practice, become a differentiating condition affecting capacity to take advantage of the general privilege of obtaining review of a criminal conviction. But Griffin does not articulate a principle to measure the sweep of this new "equal protection" rule regarding poverty. If mere poverty-influenced differences in capacity to enjoy opportunities offered by the state render a state's program unconstitutional, then tuition would have to be abolished in state universities and necessitous public school students would have to be provided with state sustenance so that they could complete their education. The social interest in education would appear to be as deep as the interest in equitable criminal procedures.

The relevance of Griffin to legislative apportionment lies in its illustration of a tendency to decide "equal protection" cases without ever clearly identifying the aspect of the particular discriminatory effect which makes it also "unreasonable," "invidious," and hence unconstitutional. The essence of a successful equal protection plea, outside the field of race, is a showing not merely of "discrimination" or differential treatment, but a showing that the "discrimination" or differential treatment derives from an unreasonable classification.

This vagueness in Griffin in 1956 on the substantive meaning of equal protection troubled Justice Harlan, and his reaction presaged his opinion years later in Baker $v$. Carr, where he and Justice Clark were the only ones to try to come to grips with the essential meaning of equal protection. In his Griffin dissent he felt that a simplistic equal protection approach, focused essentially on the differentiating factor of poverty, ignored the real issue of why poverty would be an impermissible conditioning factor in criminal appeals but-for the present at least-a permissible conditioning factor in access to a state university. He did not see how poverty as a classifying factor could have one meaning in one equal protection case and a different meaning in another. The answer, he felt, was to recognize Griffin as not an equal protection case at all but as a due process case involving a particular, identifiable, and relatively narrow concept of fundamental fairness regarding criminal appeals. He said:210

... the issue here is not the typical equal protection question of reasonableness of a "classification" on the basis of which the State has imposed legal disabilities, but rather the reasonableness of the State's failure to remove natural disabilities. The Court holds that the failure of the State to do so is constitutionally unreasonable in this case although it might not be in others. I submit that the basis for that holding is simply an unarticulated conclusion that it violates "fundamental fairness" for a State which provides for appellate review, and thus apparently considers such review necessary to assure justice, not to see to it that such appeals are in fact available to those it would imprison for serious crimes. That of course is the traditional language of due process . . . and I see no reason to import

${ }^{216} \mathrm{Id}$. at 35-36. 
new substance into the concept of equal protection to dispose of the case, especially when to do so gives rise to the all-too-easy opportunity to ignore the real issue and solve the problems simply by labelling the Illinois practice as invidious "discrimination."

A prime virtue of the due process approach is that it allows the Court to police the outer boundaries of governmental action, correcting particularly egregious conduct and legislative excrescences, without getting into the detailed process of equating group with group. Legislative apportionment cases have been fought typically as equal protection cases. The time may come, however, when this more generalized due process approach, with its protential avoidance of the details of districting, may appear to be a more judicially workable approach than the equal protection approach.

(2) Equal Protection and Political Processes. Prior to Baker v. Carr, the Colegrove precedent ruled the legislative apportionment field. There was one case, however, as yet neither reversed nor clearly modified, which bears significantly on the question of the application of the equal protection clause to alleged malapportionment. In Snowden $v$. Hughes ${ }^{217}$ the Court stated the basic premise that it takes more than a denial of a right conferred by state law to constitute a violation of equal protection, "even though the denial of the right to one person may operate to confer it on another." 218 It then stated the following oft-quoted rule: $:^{210}$

The unlawful administration by state officers of a state statute fair on its face, resulting in its unequal application to those who are entitled to be treated alike, is not a denial of equal protection unless there is shown to be present in it an element of intentional or purposeful discrimination. This may appear on the face of the action taken with respect to a particular class or person ... or it may only be shown by extrinsic evidence showing a discriminatory design to favor one individual or class over another not to be inferred from the action itself. ... But a discriminatory purpose is not presumed. . . . there must be a showing of "clear and intentional discrimination."

As applied to the Snowden facts this meant that the action was dismissed for failure to state a cause of action. The petitioner did not allege that what was done to him-refusal to certify him as a nominee for the Illinois legislature even though he had received sufficient votes-was done so that somebody else could obtain the nomination, or that somebody else in fact did obtain the nomination to the particular office to which Snowden was entitled. There were two nominations to be made, under a prior political party agreement, and Snowden, who ran second, was therefore entitled to one of the nominations. The fact that the candidate who ran first was certified by the Canvassing Board as one of the nominees was immaterial because his relationship was to a different "office" than the one improperly denied to Snowden.

Other language of the Court in this case leaves some uncertainty concerning the essence of an equal protection claim, and what must be alleged to constitute a cause of action. It is clear that $A$ does not show an equal protection cause of action 
merely. by showing wrongful treatment of himself at the hands of the state. Would it be sufficient for $A$ to allege, additionally, that the injurious treatment of him was motivated by a desire to render different treatment, in relation to this same matter, to $B$, which desire was effectuated? Would this constitute, in the Court's words, "intentional or purposeful discrimination"? In particular, in the Snowden situation, would the defect in the complaint have been cured merely by adding that the nomination was given, instead, to $M r . X$ ? If Snowden were rejected and $X$ certified on the ground that Snowden unlike $X$ was a member of a disfavored racial or religious minority, all might agree that this stated a good cause of action. But suppose Snowden and $X$ were both white Presbyterians and the Canvassing Board's action was allegedly motivated by (a) personal animosity, ${ }^{220}$ or (b) a feeling that Snowden, unlike $X$, was a party wrecker, or (c) a feeling that Snowden was too old and ill and would not live out the term, or (d) a feeling that Snowden, unlike $X$, was too uneducated for the position. Assuming that each of these actions would be wrongful, would they also constitute an equal protection cause of action in the light of the Court's admonition in the Snowden opinion that a "construction of the equal protection clause which would find a violation of a federal right in every departure by state officers from state law is not to be favored."

In its relation to legislative apportionment Snowden at least seems to indicate that there must be a showing not merely of population disparity among districts, but proof of a conscious scheme to have disparity of a particular kind, e.g., urban-rural, and accomplishment of that scheme in that Group $A$ actually received what Group $B$ was entitled to. But there is still further complexity in building from Snowdenor the Snowden dicta as to what would constitute a good cause of action-to legislative apportionment.

Suppose that $A$ alleges different treatment of himself and $B$ in relation to the same matter, but neither mode of treatment taken by itself is a violation of state law, unlike the Snowden situation. The typical legislative apportionment case would seem to fall in this category. Does mere difference in treatment, in some situations, constitute a violation of equal protection? The Court in Snowden spoke of "unequal application to those who are entitled to be treated alike," ${ }^{222}$ as being a component of the claim, although not enough in itself. But who are entitled to equal treatment? Is this an independent federal question?

The foregoing analysis suggests that at bottom the content of the state action is the crucial thing. What is required is not just a showing of differential treatment but the making of a distinction between permissible and impermissible governmental purposes. And this seems to sound more in due process than equal protection. At this point, has the Court opened a new door to judicial re-evaluation of substantive legislative purposes?. Will it recreate the broad judicial discretion which

${ }^{220}$ Cf. Burt. v. City of New York, ${ }_{5} 6$ F.2d 79r (2d Cir. 1946); Hoffman v. Halden, 268 F.2d 280 (9th Cir. r959).

${ }^{321}$ Snowden $\mathrm{v}$. Hughes, supra note $2 \mathrm{I} 7$, at $\mathrm{II}-\mathrm{I2}$.

${ }^{322} I d$. at 8 . 
figured so prominently in the actions of the pre-1937 Court in measuring state economic legislation by judicial concepts of due process?

(3) State Regulation and Taxation. Although cases like Morey v. Doud ${ }^{223}$ and Williamson v. Lee Optical $\mathrm{Co}^{224}$ continue to arise and find their way into the casebooks, such life and verve as this category ever possessed largely expired with the 1930's. In the economic field the test has come to be not the existence of discrimination but the reasonableness of the statutory scheme of classification. The "rules," as codified by Justice Van Devanter in rgro and oft-repeated since, are: ${ }^{225}$ (I) equal protection permits classification, i.e., discrimination, if the classification is reasonable and not purely arbitrary; (2) an apparently reasonable classification is not invalidated because lacking in mathematical nicety or productive of some inequality; ${ }^{226}$ (3) if facts making a classification reasonable can be conceived, their existence at the time of enactment must be assumed; ${ }^{227}$ (4) the one who challenges a classification formula has the burden of showing it has no reasonable basis and is essentially arbitrary.

Aided doubtless by the fourth rule allocating the burden of proof to the assailant of the economic legislation, the Court more often rejected than sustained the challenge. But a presumption of constitutionality does not serve to explain the cases where the Court sustained the challenge, and if one searches the cases for elucidation of principles as to the limits of the presumption of constitutionality he will meet only disappointment. In Morey v. Doud, ${ }^{228}$ for example, the Court split sixthree against the constitutionality of an Illinois statute requiring all firms issuing and selling money orders to obtain a license, but exempting the American Express Company.

Neither the reason for the decision nor the cause of the split in the Court is well explained in the decisions. It is hardly satisfying to revert to the second rule listed above and simply say that equal protection is not a matter of mathematical nicety so that the Court has what Justice Holmes called "sovereign prerogative of choice." With such vagueness should not statutes be sustained under the normal judicial review postulate of a presumption of constitutionality? Or should the facts rule, yielding varying sets of presumptions? For example, should the presumption of constitutionality be balanced with a presumption of unconstitutionality where, as in Morey, it is alleged that the statute favors the big company against the small companies? The opinions in the cases indicate that the game of presumptions-made all the more interesting by keeping them hidden-can be played on an especially rich field in regard to equal protection. Possibilities include a presumption for a competitive,

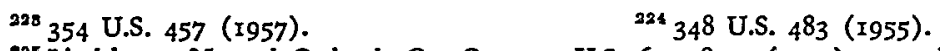

${ }^{220}$ Lindsley v. Natural Carbonic Gas Co., 220 U.S. 6r, 78-79 (IgII), quoted approvingly in Morey v. Doud, 354 U.S. $457,463-64$ (1959). Because civil rights-equal protection cases are notable by their failure to discuss equal protection at length, other areas must be appealed to for guidance regarding the standard created by the clause.

${ }^{210}$ Allied Stores v. Bowers, 358 U.S. 522, 527-28 (1959), citing intervening authorities.

227 McGowan v. Maryland, 366 U.S. 420, 425-26 (r96r), citing intervening authorities.

${ }^{228} 354$ U.S. 457 (1957). 
open market, ${ }^{229}$ a presumption for small as against big business, and a presumption for a national concern against the favored local concern.

\section{B. Apportionment Standards: The Clark-Harlan Discussion}

Both the original raison d'etre and the recent judicial heyday of equal protection have been its use to implement the one clear purpose of the Civil War Amendmentsincorporation of the Negro into the body politic. ${ }^{230}$ These racial cases, perhaps more than all the others, provided an important part of the backdrop against which Justices Clark and Harlan, in their concurring and dissenting opinions respectively in Baker v. Carr, worked out their thoughts on the application or non-application of equal protection to apportionment. Indeed, the district court judge in the Hawaiian apportionment case in 1956 made explicit reference to the egalitarian thrust of the race cases in support of his announced decision-never implemented-to grant the relief requested. ${ }^{231}$

And yet, of all the past precedents from which enlightenment on the substantive meaning of equal protection may be sought for the purpose of solving the apportionment issue, probably none are less helpful or relevant than the race cases. Race is by definition a black and white matter. The constitutional command was explicitly shaped with the freed Negro in mind. Apportionment, however, becomes a woefully fuzzy matter when one goes beyond the one-man-one-vote slogan and identifies the many other elements which have some rightful or plausible appeal to enter into the structuring of consent and leadership, of responsiveness and responsibility, of majoritarianism and representativeness, of concentration and diffusion of political power.

(I) Justice Clark. Justice Clark was prepared to decide the merits on the basis of the undisputed facts in the record and to conclude that "the Tennessee apportionment statute offends the Equal Protection clause."232 Indeed, he suggested that the majority had so held, "at least sub silentio,"233 and thought it unfortunate that there was a remand to the district court "for it to make what is certain to be that formal determination."234

The content of Justice Clark's federal standard, which Tennessee had violated, is not easily deduced from his opinion. On the one hand, it is clear, as he himself stated, that he rejected the idea that "numerical equality of representation throughout a State is constitutionally required."235 On the other hand it is not clear that

290 Allied Stores v. Bowers, supra note 226.

${ }^{280}$ Slaughterhouse Cases, 83 U.S. ( 16 Wall.) 36, 67-72 (1873). "We do not say that no one else but the negro can share in this protection. ... But what we do say, and what we wish to be understood is, that in any fair and just construction of any section or phrase of these amendments, it is necessary to look to the purpose which we have said was the pervading spirit of them all, the evil which they were designed to remedy, and the process of continued addition to the Constitution, until that purpose was supposed to be accomplished, as far as constitutional law can accomplish it." Id. at 72.

${ }^{281}$ Dyer v. Kazuhisa Abe, 138 F. Supp. 220, 236 (D. Hawaii 1956), discussed in text supra notes $52-62$.

${ }^{289}$ Baker v. Carr, 369 US. I86, 258 ( 1962 ).

${ }^{233}$ Id. at $26 \mathrm{I}$.

${ }^{235} I d$. at 260 . 
he even found a constitutional mandate to recognize population factors in devising an apportionment formula for either house of the legislature. His reason for discussing county population figures so much in his opinion was not to evaluate compliance with some federal mandate phrased in population terms. Rather it was to explore one possible basis for concluding that Tennessee's arrangement of state legislative districts did comply with a federal mandate that state classification for any given governmental activity or function be done under an identifiable and intelligible principle-whether formally announced or not-consistently applied. Because Tennessee's state constitution itself called for an apportionment formula primarily based on population, and because numerical equality of representation was the only apparent principle that Tennessee may have tried to follow, he did not have to reveal his thoughts on the constitutionality of a county equality principle, consistently followed, for one or both houses of the legislature.

The essence of his position in this case seems to be that "invidious discrimination," i.e., discrimination of the kind constitutionally forbidden, exists when two factors are shown: first, that a "classification" pattern exists in regard to a particular governmental activity or function, whether formally announced or not; and second, that the classification pattern has no underlying rational, ordering principle, consistently followed. He does not clearly identify the "class" in Tennessee's pattern of classification but he seems to be thinking of the county as the building block in the state's apportionment system. Some counties, as grouped into legislative districts, have more than one representative. Others, as similarly grouped, have a fractional representative. But there seemed to be no rational principle, in terms of population size or any other factor, which determined that a given county was in a "class" having a fractional representative, while another county was in a "class" having more than one representative.

He spoke of Tennessee's apportionment as "a topsy-turvical of gigantic proportions" ${ }^{\text {"236 }}$ and as "a crazy quilt without rational basis." even show a conscious "attempt to effect a rural-urban political balance"238 by underrepresenting all urban counties and overrepresenting all rural counties. Taking a population of 10,000 as a break point, tabulations showed that among "rural" counties of less than 10,000 population there were significant disparities in representation. Similarly, among "urban" counties of more than 10,000 population there were significant disparities.

Justice Clark's equal protection standard as formulated for this case has the appeal of simplicity, would provide a basis for deciding the case-setting aside for the moment the question of remedy-and would leave maximum room for state discretion in deciding what rational policy consistently to follow. Close scrutiny, however, reveals that it is an incomplete, if not defective, formulation of an equal protection standard. The general thrust of his opinion, and his use of the terms "topsy-turvical" and "crazy quilt without a rational basis," indicate that he is using the term "ra-
${ }^{230} \mathrm{Id}$. at 254 .
${ }^{238} \mathrm{Ibid}$.
${ }^{388}$ Id. at 255 . 
tional" simply in the sense of "intelligible." What, then, of the case where there is a rational-in the sense of intelligible-ordering principle, which is consistently followed, but which is in itself intrinsically unreasonable? That, precisely, was Brown v. Board of Education, ${ }^{239}$ and the Court held unconstitutional the resultant racial segregation in the public schools. Can Justice Clark's formulation of the equal protection standard be rounded out and perfected simply by adding the additional factor that the rational policy, consistently followed in setting up the classification pattern, must also be "reasonable"? Since "reasonableness" is the language of due process this would link the two clauses ${ }^{240}$-due process and equal protection-and provide two levels of unconstitutionality: the first, where there is no rational plan at all; the second, where the rationalizing or ordering principle offends a fundamental sense of fairness, decency, and justice.

The Court will be pushed to consider this second level of unconstitutionality in any apportionment case where the apportionment is under a rational policy-which Justice Clark did not find in Tennessee-of county equality or of consistent underrepresentation of urban counties and overrepresentation of rural counties. What then will be the content of the standard of unreasonableness? In Griffin v. Illinoi ${ }^{241}$ the fact of poverty was deemed to be an unreasonable basis for denying appeals to pauper defendants who could not afford a trial transcript, while allowing appeals to defendants who differed only in being able to afford a trial transcript.

In the context of legislative apportionment, it is obvious that the conclusion of "reasonableness" or "unreasonableness" will be influenced mightily by the manner in which the burden of proof on the issue is allocated, and by the manner in which presumptions are handled. These are the factors which seem to explain the split in Baker v. Carr between Justices Clark and Harlan.

Both start from the premise that the constitution does not require the one-manone-vote principle. But Justice Clark then takes the obvious mathematical disparity between urban counties of similar size, inter se, and rural counties of similar size, inter se, as warranting the placing of the burden on the state, as the causative force, for showing that the disparity rests on a rational-and perhaps also intrinsically reasonable-classifying principle. Justice Harlan looks at the same figures but is not fazed because he places on the plaintiffs the burden of showing that the obvious population disparity is not simply the product of "all other factors justifying a legislative determination of the sort involved in devising a proper apportionment of State Legislatures."242 And he might have added that under the Snowden v. Hughes principle there additionally should be proof of "an element of intentional or purposeful discrimination,"243 not just a showing of differences. ${ }^{244}$

${ }^{289} 347$ U.S. 483 (1954).

${ }^{210}$ Compare Boyd v. United States, II6 U.S. 616 (1886), linking the fourth and fifth amendments in certain situations, relied on by Justice Black in his concurring opinion in Mapp v. Ohio, 367 U.S. 643 (Ig6I).

${ }_{211}^{21} 35$ I U.S. 12 (1956).

36s Baker v. Carr, supra note 232, at 34I (Appendix to Justice Harlan's dissenting opinion).

${ }_{248} 321$ U.S. I, 8 (1944).

24- Justice Harlan's view of the relevance of statistics is further elaborated in the appendix to his dis- 
(2) The Presumptions-Burden of Proof Game. Regarding this vital question of burden of proof, so strikingly illustrated in the contrasting approaches of Justices Clark and Harlan, a comparison of Baker with the "all-white jury"245 cases where presumptions also played a major role, is instructive. The premise in the "all-white jury" cases that "all-white juries" are not illegal per se, and hence are not grounds in themselves for reversal of convictions of Negro defendants, is analogous to the ClarkHarlan premise that absolute numerical equality of representation throughout a state is not constitutionally required. The premise in the jury cases is qualified by the rule that continued existence of all-white juries over a time period creates a presumption that the absence of Negroes does not result solely from the operation of legitimate -i.e., racially neutral-selection factors. This qualifying rule has its analogy in Justice Clark's view, not shared by Justice Harlan, that continued population disparities raise a presumption that an illegitimate classifying factor is operating. The effect of the presumption in either instance is to put the burden on the state to show absence of improper classification factors.

But the analogy is incomplete. Racial motivation is the illegitimate hidden factor in the jury cases, which the Court reaches by means of the presumption after proof of absence of Negroes in the jury panel. What is the illegitimate hidden factor in the Tennessee apportionment case, which the Court reaches by means of presumption after proof of population disparities among districts? ". . . aye, there's the rub," as Justice Frankfurter exclaimed. 246

Race not being involved, there remain two other possible illegitimate hidden factors in the apportionment situation. First, the Court could create a basic rule, as a matter of constitutional law, that the constitution requires numerical equality in representation, unless intrinsically reasonable and consistently used grounds for deviation can be shown. Second, the Court could create a constitutional rule that apportionment must be done under some intelligible and consistently used formula, without pre-judging at all the question of the role that population or other factors should play in the formula. Although the general thrust of Justice Clark's opinion seems to point in the direction of the second of these two approaches, his closing peroration on representative government suggests identification with the first approach. ${ }^{247}$

senting opinion: "The fault with a purely statistical approach to the case at hand lies not with the particular mathematical formula used, but in the failure to take account of the fact that a muititude of legitimate legislative policies, along with circumstances of geography and demography, could account for the seeming clectoral disparities among counties. The principles set out in the Tennessee Constitution are just some of those that were deemed significant. Others may have been considered and accepted by those entrusted with the responsibility for Tennessee's apportionment. And for the purpose of judging constitutionality under the Equal Protection Clause it must be remembered that what is controlling on the issue of 'rationality' is not what the State Legislature may actually have considered but what it may be deemed to have considered." Baker v. Carr, supra note 232, at 345.

${ }^{365}$ The leading case is Norris v. Alabama, 294 U.S. 587 (I935), where evidence was adduced that no Negro had ever been known to serve on any jury, and that there were Negroes who satisfied the legal qualifications. See also Patton v. Mississippi, 332 U.S. 463 (1947), regarding "duty of the State to try to justify" the exclusion where it had continued over several years.

240 Baker v. Carr, supra note 232, at 269.

217 Although Justice Clark does allude to the noncompliance with Tennessee's own state constitution, id. at 254 , he does not seem to dispute the Frankfurter-Harlan observation that it has no relevance 
(3) Justice Harlan. Part of Justice Harlan's discussion of the "standard" issue was devoted to rejection of any thought that the fourteenth amendment commands that each vote have approximately equal weight. On this point, as already seen, Justice Clark is in agreement. The remainder of his dissent was devoted to a rejection of the idea, which was part of Justice Clark's thesis, that Tennessee's apportionment system had no rhyme or reason and was a mere "capricious classification of voting strength."248

Implicit in this part of his opinion and his supporting Appendix seemed to be the idea that an apportionment which was merely a "capricious classification" would, without more, be a constitutional violation without need to specify any affirmative constitutional requirements regarding relative share of voting strength to which particular persons or groups might be entitled. This view is supported by the phrasing of this question by Justice Harlan: "What then is the basis for the claim made in this case that the distribution of state senators and representatives is the product of capriciousness or of some constitutionally prohibited policy?"249 Accordingly, Justice Harlan would differ from Justice Clark mainly on the facts, on this branch of the case.

It was also quite clear that if a state's apportionment cleared the "capriciousness" hurdle, Justice Harlan would be at a loss to see how the fourteenth amendment imposed any limitations-apart from such familiar categories as race and religion-on the state's discretion in selecting and utilizing apportionment factors. "Surely," he felt, "it lies within the province of a state legislature to conclude that an existing allocation of senators and representatives constitutes a desirable balance of geographical and demographical representation, or that in the interest of stability of government it would be best to defer for some further time the redistribution of seats in the state legislature."250 $\mathrm{He}$ noted Justice Stewart's disclaimer that the majority opinion contained any suggestion that the Federal Constitution commands any particular kind of legislative apportionment, or that it commands according to each voter approximately equal electoral strength. Having thus disposed both of the capriciousness argument and the possibility of violation of any more intrinsic standard, he found nothing left of the complaint.

\section{$\mathrm{V}$}

\section{Post-Baker v. Carr Cases: Quest for a Standard}

Pending further enlightenment from the Supreme Court the quest for a federal standard of legislative apportionment is being pursued primarily in a number of federal and state court cases in several states. The only additional hint of possible

except as a possible basis for showing that some intelligible classification principle is being used. Id. at 325 et seq. and 332 .

${ }^{2 \times 8}$ Id. at 334. His opinion on this question was supported by an Appendix entitled "The Inadequacy of Arithmetical Formulas as Measures of the Rationality of Tennessee's Apportionment." He found a conscious choice of geography over people which is "rational" though perhaps unwise.

${ }^{260}$ Id. at 335 . (Emphasis added.)

250 Id. at 336 . 
Supreme Court views came a month after Baker v. Carr. In a brief order the Court remanded Scholle v. Hare, ${ }^{251}$ which challenged Michigan's system of fixed geographic representation in the state senate, to the state supreme court for reconsideration in the light of Baker v. Carr. There are differences, two unimportant and two quite significant, between the facts of Baker and the facts of Scholle. Unlike the Tennessee situation, the Michigan apportionment was in conformity with the state constitution, and had also been approved by popular referendum in 1952 . These two factors are unimportant because variant state practices and desires do not control federal standards. At most a nationwide sentiment or practice might condition the Court's view of the outer boundaries of reasonableness.

One of the two significant distinctions is that the Michigan case involves only the state senate, thus raising the question whether the federal constitution requires approximate numerical equality of representation in both houses of a state legislature. The other significant distinction is that the distribution of seats in the Michigan senate may be on a rational basis-that is, according to an intelligible principle of geographic representation, rather than on the unprincipled and capricious basis which concerned Justice Clark in the Tennessee case. The decision to remand Scholle $v$. Hare was correct, however, assuming the correctness of the explanation by Justices Clark and Stewart that the Court did not know from the record whether the Michigan court had decided the case on the merits of the constitutional claim, or had dismissed under the Colegrove doctrine, now repudiated by Baker.

\section{A. Idaho and Alabama}

A scant few days after Baker v. Carr the Idaho Supreme Court refused to void the current apportionment of the Idaho legislature, but threw little light on the question of standards because the case had been handled primarily as a state constitutional law case. ${ }^{262}$ The fourteenth amendment was treated cursorily and on this branch of the case the Idaho court took its guidance from Justice Stewart who had stressed that the Court in Baker was settling nothing in regard to the merits and had not repudiated the earlier dictum of the per curiam opinion in MacDougall v. Green that: $:^{253}$

... [the Equal Protection clause does not] deny a State the power to assure a proper diffusion of political initiative as between its thinly populated counties and those having concentrated masses, in view of the fact that the latter have practical opportunities for exerting their political weight at the polls not available to the former.

${ }^{252} 369$ U.S. 429 (1962). Justice Harlan would have dismissed for want of a substantial federal question. Unlike the majority he felt the Michigan court already had reached the merits, and that to remand now in the light of Baker $v$. Carr was misleading unless the majority in Baker meant much more than they said. For later developments in Michigan, see text infra at note 2732 .

${ }^{252}$ Caesar v. Williams, 37r P.2d 24I (Idaho 1962). The effect was to perpetuate a system under which $56 \%$ of the people had only $36 \%$ of the representatives and $18 \%$ of the senators.

${ }_{258}$ Id. at 249, as derived from MacDougall v. Green, 335 U.S. 28I, 284 (1948). Rehearing was denied, May 8, r962, despite plaintiff's vigorous assertion that the decision and opinion of the Idaho Supreme Court had been an "abdication by the Majority" of their duty to render a decision under the fourteenth amendment. Brief of Plaintiff-Respondent on Rehearing, p. $1_{3}$. 
Additionally, there was a timeliness factor because the court noted that the Idaho legislature had not had ample opportunity to examine fully the impact of the 1960 census on the state's apportionment.

In the Alabama case the three-judge federal district court on April r4, 1962, assumed a population formula in voiding the existing apportionment and calling for action by July 16 , I962, to avoid court-arranged reapportionment. ${ }^{254}$ But the Alabama Constitution specified a population formula-with, however, important modifications ignored by the court ${ }^{255}$-and the court did not say whether the federal equal protection clause likewise would have required use of a population formula for either or both houses. The court was bemused by the state's violation of its own constitution and then, like Justice Clark in Baker, went on seemingly to adopt sub silentio a federal population principle of undetermined dimensions. It warned that if the legislature did not act, or did not meet the "constitutional standards"256 which the court had not specified, the court would then reapportion before the November 1962 election, taking its cue from Justice Clark's opinion in Baker. It might "start with the existing assembly districts, consolidate some of them, and award the seats thus released to those counties suffering the most egregious discrimination," thereby releasing "the strangle hold now on the Assembly and [permit] it to redistrict itself."257

The resultant special session of the Alabama legislature failed to produce an acceptable reapportionment plan. In late July the court ordered into effect a makeshift reapportionment formula using parts of two different plans passed by the legislature, and affecting both houses; and the state decided to accept the decree. ${ }^{257 \pi}$ The court warned that the legislature elected in November 1962 must go further than the standby plan or risk further judicial intervention.

Significantly, the court indicated that population must be considered to some extent in regard to the apportionment formula for each house of the legislature. Alabama thus became the first state in which federal judges assumed the function of participating directly in the policy choices regarding a particular reapportionment plan, rather than merely approving or disapproving legislative handiwork.

\section{B. Georgia and Michigan}

The first explicit treatment of the standard problem came one month after Baker v. Carr when a federal district court in Sanders v. Gray ${ }^{258}$ nullified Georgia's county unit system of weighting votes for nomination for state office. The disparity between the weight of a vote in the most populous county (Fulton-556,226 population, 6 unit votes), and the weight of a vote in the least populous county (Echols-1876 population, 2 unit votes), had been 99 to $\mathrm{I}$, in terms of population. In other words,

${ }^{254}$ Sims v. Frink, 30 U.S.L. WeEK 2512 (M.D. Ala.) (U.S. April I4, 1962).

${ }^{255}$ See Chart III in Appendix regarding state constitutional provisions concerning apportionment.

${ }^{280}$ Sims v. Frink, stspra note $254 . \quad{ }^{267}$ Ibid., quoting Justice Clark. col. 8 .

${ }^{267 \approx}$ N.Y. Times, July 22, I962, p. I, col. 2; id. July 24, I962, p. I5, col. 4 ; id. July 26, 1962, p. 24,

${ }^{258} 203$ F. Supp. 158 (N.D. Ga. 1962), appeal docketed, No. 959, 370 U.S. 921 (1962). 
each of the "unit votes" in Fulton County represented 92,539 people; each of the "unit votes" in Echols County represented $93^{8}$ people. ${ }^{259}$ Even as modified the preceding day in a legislative special session, the "new system missed the mark in two respects: first in failing to accord the unit of the plaintiff a reasonable proportion of the whole, and second in failing to accord the units representing a majority of the population a reasonable proportion of the whole."260

The court recognized that "it may appear doctrinaire"281 to attempt to reduce equal protection to precise rules. Nevertheless it went ahead and did so after first reviewing a number of relevant factors, not all of which were obviously related to the rule formulated. ${ }^{262}$ In its final formulation the court flatly embraced numerical equality as a major premise, thus apparently ruling out use of geographic or other weighting even if done on a principled, regularized basis. But then it added the odd qualification that no population disparity would be "invidiously discriminatory" which did not exceed the disparity among states that exists in the allocation of votes in the electoral college or seats in the House of Representatives. The court said: ${ }^{263}$

[W] ... hold that a unit system for use in a party primary is invidiously discriminatory if any unit has less than its share to the nearest whole number proportionate to population, or to the whole of the vote in a recent party gubernatorial primary, or to the whole vote for electors of the party in a recent presidential election; provided no discrimination is deemed to be invidious under the system if the disparity against any county is not in excess of the disparity that exists against any state in the most recent electoral college allocation, or under the equal proportions formula for representation of the several states in the Congress, and provided that it is adjusted to accord with changes in the basis at least once each ten years. This is a "judicially manageable standard" contemplated in Baker v. Carr.

The rule that no state may have fewer than one seat in the House of Representatives, no matter how small its population, causes disparity by proportionately inflating the voice of the small state. But the more striking disparities occur in the electoral college because of the rule that no state, no matter how small in population, may have fewer than three electoral votes-one for each of its two senators and

250 The court worked out a mere IO-I discrimination against Fulton County by relating the population and unit votes of each of these two counties to the total of 4 Io county unit votes rather than by comparing the two counties in terms of voter status. It pointed out that Fulton with I4.II per cent of the state's population had only 1.46 per cent of the total county unit votes, while Echols with .05 per cent of the population had .48 per cent of the total units. Id. at 160 .

These different ratios, each computed by a rational process, indicate that at the very least Baker $v$. Carr may have opened a new frontier of gamesmanship.

$200 \mathrm{Id}$. at 170 . The last minute change by the legislature boosted Fulton County to 40 unit votes. This means that each voter in Echols still had about fourteen times as much political weight as a voter in Fulton.

${ }^{201}$ Id. at 170 .

'202 Factors mentioned included the "rationality of state policy," (derived from Justice Clark in Baker v. Carr), whether the system was "arbitrary," "historical basis in our political institutions," "presence or absence of political remedy," the factor of "delicate relationship between federal and state governments under the Constitution." Id. at r68-70.

${ }^{200}$ Id. at 170. (Emphasis added.) 
one for its congressman. Electoral college disparities thus become the measure of equal protection of unit votes under this decision.

The anomalous and unsatisfying character of this electoral college ratio test, if generalized as a standard for application of the fourteenth amendment in this field, becomes apparent as soon as it is subjected either to a practical or to an historical and conceptual analysis. Practically, it would allow disparities as great as or greater than those complained of in much of the recent litigation about congressional districts or state legislative apportionment. The ratio also would vary with the chance factor of differential growth rates as between the most populous and least populous states. A permissible disparity of 5 to I would result from this standard at present because in the smallest state, Alaska, each of the three presidential electors speaks for 75,389 of the total population of 226,167 , while in the largest state, New York, each of the forty-three presidential electors speaks for 390,286 of the total population of $16,782,304 \cdot{ }^{204}$

As applied to congressional districts, such a ratio would mean that citizens in a district of $r, 000,000$ population would have no constitutional ground for complaint so long as the small district was not less than 200,000. But their prospects for relief would be considerably improved if there were a population boom in the smallest statel From a practical standpoint, therefore, the electoral college ratio test suggested by the district court in Georgia is a yardstick made in Wonderland for Alice.

The standard rests on no better ground when analyzed historically and conceptually. The electoral college apportionment, like the apportionment in the Federal Congress of which it is a carbon copy, is a product of the great compromise on representation on which our federal union is based. The familiar decision at the constitutional convention to create a bicameral legislature, following the New Jersey plan of equality of the states in one house and the Virginia plan of representation proportioned to population or wealth in the other house, was a necessary structural compromise entered into by "sovereign" states. It was so vital and necessary that the principle of equal representation in the Senate was even exempted from the power of constitutional amendment. ${ }^{265}$ The same apportionment system

\footnotetext{
${ }^{204}$ Based on 1960 census figures and the reapportionment of the House of Representatives effective in 1962 .

${ }_{265}$ U.S. CoNST. art. V. Concurrently it may be noted that the Northwest Ordinance of 1787 specified that the "inhabitants of the said territory shall always be entitled to the benefits . . . of a proportionate representation of the people in the legislature ..." without distinguishing between upper and lower house. Doctments Illustrattve of the Formation of the Union of the American States 5I (Tansill ed. 1927). In the context of the time, the purpose was to devise a plan of government for a sparsely settled territory, largely devoid of political tradition, of established and traditional local units, of customary sectional sub-loyalties, and the multifarious other elements which complicate apportionment in a long-established society. The Ordinance devised a representation system keyed to the one readily identifiable element-an expanding population of settlers. The pertinent provisions, in addition to the clause quoted above, were as follows: "So soon as there shall be five thousand free male inhabitants, of full age, in the district, upon giving proof thereon to the governor, they shall receive authority, with time and place, to elect repiesentatives from their counties or townships, to represent them in the general assembly: Provided, That for every five hundred free male inhabitants there shall be one representative, and so on, progressively, with the number of free male inhabitants, shall the right of representation increase, until
} 
was adopted for the electoral college in order to apply to the Presidency the same weighting of the states that applied to the Congress. The disparities among the states regarding the electoral college are thus a special case, in the purest sense of the term.

In the light of these considerations it would appear doubtful that the Supreme Court would endorse the district court's formulation of the standard when it reviews Sanders v. Gray in the October Term 1962, whatever the outcome of the case itself. In the meantime, there was no stay of the injunction the district court issued against applying the unit system in determining the outcome of races for governor, senator, and other state-wide offices in the September Ig62 primary. ${ }^{268}$

Sanders v. Gray is not to be confused with two other Georgia cases: one seeking reapportionment of the state legislature, the other seeking revision of the congressional districts. In the former suit, Toombs v. Fortson, ${ }^{267}$ a federal district court in May I 962 called for reapportionment of at least one house of the legislature on a population basis by the January 1963 session, but deferred issuing an injunction to give the state a "reasonable opportunity ... to meet the constitutional standards here laid down . ..."268 A month later, a federal district court dismissed the congressional district suit, Wesberry $v$. Vandiver, ${ }^{269}$ on a mixture of grounds. It doubted that Baker had reversed Colegrove in regard to congressional districts, because of the factor of involvement of a coordinate branch of the government, and it thought relief might be forthcoming from "a properly apportioned"208a state legislature which was already in sight under the Toombs v. Fortson decision. Assuming that "a properly reapportioned" legislature does eventuate, this approach to the congressional districting case is eminently sound. The state legislature is the key to congressional districting, unit vote weighting schemes, urban problems, and regular reapportionment of the legislature itself.

In Toombs v. Fortson the court was presented with a record showing disparities far in excess of the electoral college ratio test announced in the county unit case a month earlier. Computations showed that 103 counties having six per cent of the population could elect a majority of the lower house, and that eighty-four counties having twenty-one per cent of the population could elect a majority of the upper house. In holding the apportionment to be invidiously discriminatory, the court nevertheless inferred that the electoral college ratio test should not be taken as quite the absolute that it appeared to be in the county unit context in Sanders v. Gray. ${ }^{270}$ The court said that a finding of invidious discrimination might be avoided if it

the number of representatives shall amount to twenty-five; after which the number and proportion of representatives shall be regulated by the legislature. ..." Id. at 49 .

${ }^{300}$ A petition for stay was denied by the district court, and not requested of the Supreme Court. N.Y. Times, June 19, I962, p. I, col. 2.

${ }_{307} 205$ F. Supp. 248 (N.D. Ga. I962). $\quad{ }^{268} I d$. at 259.

2003 I U.S.L. WEEK 2017 (N.D. Ga.) (U.S. June 20, I962).

200 Ibid.

270 Toombs v. Fortson, supra note 267. Withoute actually saying so, the court indicated that the electoral college ratio test used in the county unit case was inapplicable to legislative apportionment. 
could be shown that the disparities were pursuant to a rational state policy, but there was no such showing here:271

No factual evidence has been presented to the Court upon which the Court can posit any finding, as a finding of fact, that a state policy exists which justifies the great disparities in legislative representation between the counties in which plaintiffs reside and the many other counties of the states whose representative strength exceeds that of Fulton County by as much as 98 to $\mathrm{I}$. We are left then to speculate as to whether there may be some rational policy, and we are forced to the conclusion that there is no policy but simply a reluctance of those with grossly disproportionate power over the legislative process to surrender such power.

It suggested, however, that a policy of having one house of a bicameral system on a geographic basis and the other on a population basis would be a rational policy, and only required Georgia to change one house by the January ${ }^{2} 963$ legislative session.

Thus, putting Sanders and Toombs together, two tentative rules appear. In elections of state-wide office holders the population principle must be embraced, disparities in weighting of votes being permitted only up to the maximum ratio found in the electoral college system of election of President and Vice President, which as shown above is now about five to one. For apportionment of state legislatures, where a factor of representation is present which is lacking in election of state-wide office holders, bicameralism is permissible. And within bicameralism gross departure from the population principle by placing one house on a geographic basis is permissible as long as the population principle is expressed in the lower house. The rationality of such a policy is supported in part by analogy to the Federal Congress, the court thought, despite a contrary dictum in Justice Douglas' dissent in MacDougall $\nu$. Green ${ }^{272}$ and despite possible inferences from the Supreme Court's remand of the Michigan state senate case ${ }^{273}$ after Baker v. Carr.

The possible contrary inferences from Scholle $v$. Hare were reinforced by the Michigan Supreme Court's 4-3 decision, after remand, invalidating the geographic formula for the state senate. ${ }^{273 a}$ It was viewed as being more a freezing of existing districts than a provision for area representation according to a rational plan. Two judges seemingly would go further and read into the fourteenth amendment the mathematical formula developed earlier in Michigan constitutional law, i.e., that permissible discretion is exceeded when an apportionment yields districts having more than double the population of others.

The Michigan court enjoined the senate primary, which was less than three weeks away, and said that the state senators would have to be elected at large in November 1962 unless appropriate legislation were enacted by August 20. United States Supreme Court Justice Stewart, however, stayed this drastic relief on the ground that new issues were involved, not covered by Baker v. Carr. ${ }^{273 b}$

\footnotetext{
${ }^{271} 1 d$. at 254 .

278 Scholle v. Hare, supra note $25 \mathrm{r}$.

${ }^{272} 335$ U.S. $281,289-90$ (1948).

178* Scholle v. Hare, 3 I U.S.L. WeEk 2059 (Sup. Ct. Mich.) (U.S. July I8, I962).

${ }^{2735}{ }_{31}$ U.S.L. WEEK roI 8 (U.S. July 3 I, 1962).
} 


\section{Maryland}

As the first judicially impelled reapportionment after Baker v. Carr, the litigation in Maryland Committee for Fair Representation v. Tawes ${ }^{274}$ is of great moment to the citizens of Maryland but throws little light on the question of the federal constitutional standard. In April, the court of appeals reversed a lower court dismissal of a reapportionment suit. In May, the lower court held that the apportionment of the lower house would violate the equal protection clause as applied to the $\mathbf{I g 6 2}$ November election, ${ }^{275}$ and the legislature in special session then enacted a stop-gap bill. ${ }^{270}$ In June, litigation was pursued in an attempt to have the lower court ruling expanded to include the state senate. ${ }^{2 \pi \tau}$

As in most of the cases gross population disparity in regard to both houses of the legislature could be shown but neither court nor counsel developed a reasonably precise, articulated theory of federal right. At the time of the hearing in the court of appeals seventy-six per cent of the state's population, concentrated in Baltimore City and four suburban counties, elected only thirty-four per cent of the state senate, and forty-nine per cent of the lower house. ${ }^{278} \mathrm{~A}$ vote in the least populous county had almost thirteen times as much weight as a vote in the most populous county.

In remanding to the lower court for a decision on the merits the court of appeals said: 279

... there is a strong implication in the Baker decision that there must be some reasonable relationship of population, or eligible voters, to representation in the General Assembly, if an apportionment is to escape the label of constitutionally-prohibited invidious discrimination.

But the court also spoke of the traditional geographic representation in the Maryland Senate and said that a "greater latitude" regarding population might be permissible there, or "possibly some different basis of apportionment."

The balance of the opinion was devoted largely to giving the lower court guidance on remedies, and here the court of appeals took a delightfully frank and creative approach. If the apportionment were held unconstitutional it should be in relation to the November 1962 election, and without impact on the existing legislature. An "at large" election should be avoided because not authorized in the state constitution and, perhaps, because the court, sub silentio, did not think it appropriate. The court could not call a special session but the governor could. If called into special session the legislature would have power, because of the overriding force of the fourteenth amendment, to itself modify the unconstitutional parts of the Maryland Constitution regarding apportionment. It could raise or lower the total number of seats in either house. Alternatively, and this was the most unusual suggestion, it could leave the

27228 Md. 412, I80 A.2d 656 (1962).

${ }^{278}$ Maryland Committee v. Tawes, 30 U.S. L. WEeK 2587 (Cir. Ct.) (U.S. May 24, 1962).

370 Washington Post, June I, I962, p. I, col. 8.

${ }^{27}$ Plaintiffs had sought a general ruling but the circuit judge had confined his decision to the House of Delegates.

${ }_{278}$ Maryland Committee v. Tawes, 228 Md. 4I2, 42I, I80 A.2d 656, 660 (I962).

${ }^{270} \mathrm{Id}$. at 434,180 A.2d at 668 .

${ }^{280} \mathrm{Ibid}$. 
representation physically unchanged but provide for fractional voting by representatives to correct the proportionate disparities. Further, the legislature's action could take the form of a stop-gap measure for 1962 , coupled with a proposed constitutional amendment, including provision for future reapportionment. The Maryland Court of Appeals thus neatly sidestepped the supposed inability to justify a continued status, de jure or de facto, for the legislature after a declaration of unconstitutionality which had so troubled the Tennessee Supreme Court ${ }^{281}$ in the state case which was a forerunner to Baker v. Carr.

All this was too much for the two dissenting justices. Forgetting that the mark of the development of the common law in the King's Courts was that power preceded precedent, they unburdened themselves of a number of observations, including the following: $:^{282}$

It [the majority opinion] directs the chancellor, upon proof of the allegations of the bill, to make a declaration striking down the provisions of one or more sections of the Constitution, but at the same time to defer the effectiveness of the declaration until after the expiration of the terms of office of the present members. I cannot understand how that can be done. But if it can, I cannot see how those members could enact legislation reapportioning and reconstituting the General Assembly in the teeth of constitutional provisions that are still in force and effect.

The lower court, the governor, and the General Assembly got the several messages. Judge Duckett on remand voided the apportionment of the lower house and issued the appropriate orders already outlined by the court of appeals. The standard of unconstitutionality for the lower house was little more than a conclusionary statement that "invidious discrimination" existed because the "extent of the disparity" had no "reasonable justification."283 The legislature in special session promptly added nineteen seats to the lower house so that the districts containing seventy-six per cent of the state's population obtained a fifty-five per cent majority in the lower house. ${ }^{284}$ The plaintiffs then indicated they would make no further challenge of the lower house until Ig66 even though not fully satisfied with the reapportionment. ${ }^{285}$

Judge Duckett's decision to defer a final decision on the constitutionality of the senate-after intimating that he thought area was an appropriate basis for one house-was reversed promptly in the court of appeals and sent back down for trial. In pleading for a declaration of unconstitutionality of senate apportionment too, the ${ }_{281}$ Kidd v. McCanless, 200 Tenn. 282, 292 S.W.2d 40 (1956).

${ }^{283}$ Maryland Committee v. Tawes, 228 Md. 412, 445, 180 A.2d 656, 674 (1962).

${ }^{283}$ Maryland Committee v. Tawes, 30 U.S. L. WEEK 2587 (Cir. Ct.) (U.S. May 24, 1962), and borrowed copy of full opinion.

284 Washington Post, June $\mathrm{I}, \mathrm{1962}$, p. I, col. 8.

285 "Appellants [plaintiffs] believe that the so-called 'stop-gap' legislation enacted at the recent Special Session of the Legislature, although belated, begrudgingly enacted, hardly equitable, much less generous, nevertheless, at least as a temporary or transitional measure, cannot successfully be attacked by appellants as inconstitutional under the Fourteenth Amendment. Accordingly the appellants have abandoned any further present court challenge to the representation now provided in the House of Delegates, at least until rg66. ..." Appellants' Answer to Appellees' Motion to Dismiss Appeal, p. 3, Maryland Committee v. Tawes, Court of Appeals, No. 94, filed June 5, 1962. 
plaintiffs articulated no detailed theory of a federal right. Rather they rested on the assertion that "if it is unconstitutional for twenty-four per cent of the population to have fifty-one per cent of voting control in one house of the legislature, a fortiori, it is unconstitutional for the same twenty-four per cent to enjoy sixty-six per cent representation in the other house of that legislature."286

However, Judge Duckett denied relief, holding that apportionment of the senate by area does not violate the fourteenth amendment so long as the lower house is fairly apportioned according to population, ${ }^{286 a}$ and the court of appeals promptly affirmed in a $4-3$ decision. ${ }^{286 b}$

\section{Tennessee}

In the home state of Baker $v$. Carr, a legislative special session in June Ig62 brought forth a mouse, but one entitled to live for one year according to a federal district court ruling two weeks later. ${ }^{287}$ In criticizing the reapportionment the court indicated two standards: first, that at least one house should be based on numercial equality of voters; second, that the other house, the senate, should at least be based on a rational plan.

\section{E. Other Actions}

In several other states either state or federal district courts have acted to void apportionments and impel special sessions of legislatures under judicial threat to assume the reapportionment function, e.g., Oklahoma, ${ }^{288} \mathrm{Wisconsin},{ }^{280} \mathrm{Mississippi},{ }^{290}$ and Vermont. ${ }^{291}$ And the list steadily grows of states in which some action has either been taken or is pending, so that almost half of the states were involved as of June $1962 .{ }^{292}$

${ }^{280}$ Petitioners' Brief on the Merits or, Alternatively, In Support of Their Motion for Summary Judgment, p. 28, Maryland Committee v. Tawes, Circuit Court for Anne Arundel County, Eq. No. 13,920, filed May 28, 1962.

${ }_{280 a}$ Maryland Committee v. Tawes, 3 I U.S. L. WeEK 2016 (Cir. Ct. Md.) (U.S. June 28, I962).

${ }^{2800}$ Washington Post, July 24, I962, p. I, col. 4.

${ }^{287}$ Baker v. Carr, 3 I U.S. L. WEEK 2003 (D. Tenn.) (U.S. June 22, 1962). See also N.Y. Times, June 23, 1962, p. 23, col. I; Washington Post, June 23, I962, p. 5, col. x. If the legislature takes no further action the case may be reopened by June 3,1963 .

${ }^{288}$ Washington Post, June 20, 1962, p. 7, col. 4 (federal district court declared apportionment invalid, deferred relief to give legislature opportunity to act). It may be noted that the district court order in Oklahoma was to a legislature of a state whose governor could be expected to add the weight of his authority, and all resources at his command, to the enforcement of the court's order. Governor Edmondson had been clected on a reapportionment platform, had already unsuccessfully tried to browbeat the legislature into reapportioning the state, and had offered an amicus curiae brief in Baker v. Carr pleading with the Court to act.

${ }_{280}$ N.Y. Times, June 9, 1962, p. 22, col. I (federal district court gave Governor Io days to call special session and warned it would appoint a master to reapportion if legislature dragged its feet). In the special session the Democratic governor vetoed three reapportionment plans of the Republican-controlled legislature. The court did appoint a special master, but as of late July he had recommended that the three-judge federal district court dismiss the suit on the ground that the present districts did not deny voters any constitutional rights. N.Y. Times, July 26,1962, p. 24 , col. 8.

${ }_{200}$ Washington Post, June 8, 1962, p. 4, col. 3 (lower state court voided legislative apportionment, asked for special session of legislature, said it would act itself if necessary).

${ }^{201}$ N.Y. Times, May I4, 1962, p. I, col:"2 (lower state court found state senate districts invalid and enjoined two counties from holding elections). The state supreme court affirmed and a special session of the legislature resulted, Washington Post, July 22, Ig62, p. 5 , col.' $x$.

${ }_{202}$ In addition to occasional compilations in the press [e.g.; N.Y. Times, 'May. 14,1962, p. I, col. 2; 
Perhaps the most interesting of the handful of qualified negative responses ${ }^{202 a}$ of the courts is Levitt v. Maynard, ${ }^{202 b}$ in which the New Hampshire Supreme Court refused to disturb that state's unique apportionment formula for the upper house of the legislature. The formula is keyed neither to area nor to population in the simple sense, but rather to the proportion of direct taxes paid by the districts. The court noted that the equalized valuations of the current districts varied within a relatively narrow range, from a high of $\$ 122,000,000$ to a low of $\$ 96,000,000$ (the ideal average being $\$ 109,000,000)$. In terms of population the figures ranged from $4 \mathrm{r}, 457$ in the most populous district to 16,829 in the least populous district. The court was especially impressed by the fact that the minimum per cent of the 1960 population necessary to elect a majority of the senate was 45.3 per cent, a percentage that compared favorably with systems in other states.

'The court concluded that it could not say that New Hampshire's system was "without rational basis or that it has produced an unrepresentative selection in the upper house of the Legislature."202c The New Hampshire case poses in sharp perspective the crucial question which will dominate current and future litigationthat is, the extent to which the fourteenth amendment requires explicit recognition of population in the apportionment formulae for either or both houses of a legislature.

\section{F. Local Legislative Councils}

Equal protection, of course, does not stop at the state level. A recent Ohio Supreme Court order to the Cleveland City Council to redistrict the city is explicable as simply an order to comply with a reapportionment duty under the city charter, ${ }^{293}$ but undoubtedly is a harbinger of a still further outreach of Baker v. Carr.

\section{VI}

\section{Evaluation of the Standard-Remedy Problem}

The experience regarding litigation started both in federal and in state courts in the first three months after Baker v. Carr has borne out the spirit if not the letter of Justice Douglas' robust optimism in his concurring opinion that "any relief accorded can be fashioned in the light of the well-known principles of equity."204

\footnotetext{
Washington Post, June 24, I962, p. E3, col. I] a monthly review of reapportionment appears in the National Civic Review. Other cases of broad interest include the Supreme Court remand to the federal district court to take a fresh look at the New York legislature, W.M.C.A., Inc. v. Simon, 202 F. Supp. 74 I (S.D.N.Y. I962), vacated and remanded, 370 U.S. 190 (1962); the Indiana cases (a lower court state judge voided the legislative apportionment before Baker $v$. Carr, and suit was also filed in federal district court).

202^ Sweency v. Notte, 31 U.S. L. WEEK 2060 (Sup. Ct. R.I.) (U.S. July 24, 1962), in which the court intimated that Rhode Island's apportionment formulac were unconstitutional, and that a federal court might order reapportionment, but said it was barred by the state separation of powers doctrine from taking action; Stcin v. General Assembly, 3 I U.S. L. WeEk 2075 (Sup. Ct. Colo.) (U.S. July 6, 1962), in which the court delayed action because neither popular initiative nor legislative redress had been exhausted.

${ }^{2025}$ 3I U.S.L. WeEK 2060 (Sup. Ct. N.H.) (U.S. July 16, 1962).

$209 \mathrm{I}$ I. at $206 \mathrm{r}$.

${ }^{203}$ Washington Post, June 21, 1962, p. 8, col. 2.

${ }^{20 *}$ Baker v. Carr, 369 U.S. 186, 250 (I962).
} 
A fair amount of judicial explication has been needed, as in Maryland, but it has been forthcoming and has been heeded. And with the Little Rock example of executive support of judicial action a recent memory, ${ }^{295}$ a calculus of horribles is not to be indulged. Further, the courts have so far been able to induce some legislative action, or hypothesize action they might themselves take along the lines of Justice Clark's concurring opinion, without contemplating use of the highly questionable device of at large election for a state legislature.

The critical question of the federal standard of fair representation, however, has been only faintly illuminated. Some of the post-Baker cases are better judged on their facts than on their opinions. When it could be shown that districts containing a majority of the population of the state-typically urban and suburban districtsdid not have majority control of either house of the legislature, the courts generally have acted. ${ }^{296}$ On such a record it would seem that the proper constitutional ground is due process-it being unreasonable and arbitrary to underrepresent so grossly such a vital democratic component as people.

It may still be essentially a due process issue when the next level of difficulty is reached. The next level involves the question whether giving majority control of one house to districts where a majority of the population resides is still insufficient where ( $\mathrm{I}$ ) the other house remains in the hands of a rural minority, and/or (2) where the majority control in the one house is still grossly disproportionate to the numerical strength of the urban-suburban majority. For example, in Maryland, reapportionment raised the districts containing seventy-six per cent of the people to majority control of the lower house-but only to a fifty-five per cent majority.

The due process clause would seem to be less appropriate than the equal protection clause-if indeed, either clause is appropriate-when further refinements are considered. Some possible refinements that readily come to mind include: (r) whether the Constitution is violated when majority control is denied to districts where a majority, but not an overwhelming majority, of the people reside, e.g., when disparity drops from Maryland's prereapportionment figure of seventy-six per cent to seventy, sixty-five, sixty, fifty-five, or fifty-three per cent; (2) whether any particular district can ever be allowed to be more than two, three, four, five times as populous as another district with the same representation; (3) as a refinement of the previous point, whether to facilitate district-to-district comparisons under an equal protection approach a constitutional rule should be formulated that no district would be constitutional if it deviated by more than a certain percentage from the "average population" obtained by dividing the total population by the total number of districts. The last-named rule relates to statutory limits which it has been suggested from time to time Congress should impose on state legislatures in regard to congressional districts. ${ }^{297}$

${ }^{205}$ Cooper v. Aaron, 358 U.S. I (1958).

200 An early exception was Idaho, text supra at notes $252,253$.

${ }^{207} \mathrm{Sec}$ text and note at note I4I supra. 
: Running through all of these possibilities will be the question of the extent to which the meaning of "equality" will vary as the challenged institutional arrangement shifts from unit voting systems to congressional districts, to state legislatures, and within state legislatures from the lower house to the state senate. These institutional arrangements have been listed intentionally in what would appear to be a descending order regarding the mandatory force of the one-man-one-vote principle. First, there can be almost no excuse for a unit vote system because the purpose is to elect a single official, e.g., governor or United States Senator, who in his single person is viewed as representing, and being responsible to, all of the people. To be sure, the President is elected under a weighted electoral college system rather than on a straight population basis, but this is a product of the initial federal compromise of 7787 . Second, as soon as one turns from unit voting to congressional districting, a qualification of uncertain weight enters. The congressional delegation represents the people of the state in the House of Representatives, the states themselves being weighted by population in the congressional apportionment. These facts evoke the one-man-onevote principle. But it is immediately qualified by the additional fact that the expectation and actual tradition has been that congressmen, through allocation to districts, would perform also a representative function within the state, thus enriching the variety of views brought to the national assembly. In representative theory there are many shades and fashions of majoritarianism, produced by differing combinations of assembly size, apportionments, districting and franchise.

Third, when one turns from congressional districts-which are a component of only half of the national legislature-to state legislatures the representative theory becomes much more complicated. Conceding that only a massed "Aye" is needed for the selection of the governor, what variety of expression should be built into the basic structure of the legislature, and what dominance should be accorded to those who in numbers, and probably in wealth, comprise the largest segment of the state? And what of checks and balances and bicameralism? Extracting a rule that at least one house should be dominated by numbers, do different considerations enter when one turns to the other house of the legislature?

In the ultimate configuration of this litigation Justice Frankfurter was undoubtedly correct when he said that plaintiffs ask the Court to be willing to make a choice "among competing theories of political philosophy," to make "an inquiry into the theoretic base of representation in an acceptably republican state."208 But, one may ask, difficult though the articulation may be, what is wrong with a Court commitment to a "democratic political philosophy?" The absence of enlightenment from past precedents, and the fact that past and present actual practices are based more on an inequality principle than an equality principle in representation, do pose difficulties.

However, the deviation between theory and practice, aspiration and accomplishment, is not unfamiliar to constitutional law and explains both the fascination and the

${ }^{208}$ Baker v. Carr, 369 U.S. 186, 300, 301 (Ig62). 
heated disputes of the subject. Analogous deviations prevailed in regard to race, prior to the Desegregation Decision, ${ }^{299}$ and in regard to state search and seizure practices and the exclusionary rule prior to Mapp $v$. Ohio. ${ }^{300}$ If a long standing contrary practice is to be taken as rendering inappropriate a new judicial rule designed to implement for the first time an immanent constitutional ideal then a number of leading decisions are questionable.

One of the most clouded, but also most precious, attributes of judicial review is the role of the Court as the "keeper of the Nation's conscience," exercising through judicial review a responsibility as well as a power to achieve a higher public morality. Political realities being what they are, it is doubtful if either the Desegregation Decision or the exclusionary rule of Mapp v. Ohio could have been initiated in Congress and ratified by three-fourths of the states as constitutional amendments. By the same token, once created by judicial review, neither rule has been undone by constitutional amendment.

The difficulties inherent in apportionment and districting litigation are subject to two limiting factors. First, as already seen, the Court may have to become specific on merits and remedies in relatively few cases. Second, the Court can choose, and probably should choose, to adopt as its standard not a principle of promoting equality-with all the logical and practical difficulties that would arise in defining what is "fair"-but rather a principle of negating proven instances of egregiously unreasonable apportionment patterns. The process of case by case identification of "unfairness," on full records but narrowly focused, is the traditional stuff of judicial review,

In short, in apportionment cases and in the associational privacy cases the true constitutional principle may not be the one asserted at all-equal protection and first amendment, respectively. The true principle may be due process, checking unreasonableness not under an absolute standard of free speech, or equality, but under a factually illuminated "balancing" formula. ${ }^{301}$ Without reaching Justice Frankfurter's question of "the theoretic base of representation in an acceptably republican state," the Court could hold, on an appropriate factual base, that a representation. system under which a major group of complainants is excluded from effective voice in either house is unreasonable because minority process is not due process. It could, and probably should, eschew detailed district by district comparisons under numerical rules of thumb, just as it has avoided detailed rules in yet another highly discretionary, but nationally necessary field-the application of the commerce clause to state regulation and taxation. And by this approach the Court would avoid also the difficult and probably fruitless quest for a showing of "purposeful or intentional"-rather than presumed-discriminations which the Snowden precedent ${ }^{302}$ may require in regard to equal protection.

\footnotetext{
200 Brown v. Board of Education, 347 U.S. 483 (1952).

${ }_{300}^{367}$ U.S. 643 (I96I).

801 Cf. Nutting, Is the First Amendment Obsolete?, 30 Gzo. Wast. L. Rev. 167 (I96r).

${ }^{802}$ Snowden v. Hughes, 321 U.S. I (I944).
} 


\section{ConczusION}

Baker v. Carr rests on a principle of judicial necessity to act to preserve the very essence of the democratic process. Its novelty is not to be minimized by distortion of earlier and generally negative precedents. It was, and remains, a very large step in the direction of close judicial scrutiny of the politics of the people. As "an eminently realistic body of men,"303 it is difficult to suppose that the Court was uninfluenced by the fact of exhaustion of non-judicial modes of relief over a period of several decades.

For the urban majority the decision may well evoke memory of the famous lines of the Declaration of Independence that prudence "will dictate that Governments long established should not be changed for light and transient causes," but that a duty to act arises from "a long train of abuses and usurpations, pursuing invariably the same Object...." The Declaration led to a new political order. The degree and character of political power shift destined to flow from Baker v. Carr remains to be seen. Much will depend on the still unresolved question of the federal standard of fair apportionment, whether ultimately phrased in the broad terms of due process or "republican form of government," or based on the tighter conception of equal protection. In some states numbers will equate closely with education, wealth, and culture; in others there may be no correlation or an inverse correlation. ${ }^{304}$

The most striking aspect of Baker $v$. Carr, viewed only a few months after the decision, is the rapidity with which old suits have been concluded in judicial orders for change-without need to experiment with new sanctions-and new suits instituted. If this seems surprising it may be because the present is too much with us and we are too prone to equate Baker v. Carr with the bitter and tedious aftermath of Brown v. Board of Education, forgetting the uniqueness of racial tension against a background of de jure slavery and a foreground of de facto serfdom. But De Tocqueville would understand the decision, because to him the thrust for equality was both the mark of American history and the touchstone of modern history.

His words are as appropriate now at the close as they were at the beginning. Writing in 1835 , he saw the development of "equality of conditions" as part of the sweep of history over a seven hundred year period: universal and durable, the development "eludes all human interference, and all events as well as all men contribute to its progress." 305 Democratic communities have "a natural taste for freedom. ... they will seek it, cherish it, and view any privation with regret. But for equality, their passion is ardent, insatiable, incessant, invincible."308

308 Bernard Taper, Gomilion versus Lightfoot: The Tuskegee Gerrymander Case 81 (xg6z).

${ }^{30 t}$ Baker v. Carr provides an interesting contrapuntal theme for the efforts to broaden the Southern Negro electorate through self-help and Department of Justice enforcement of the $x 957$ and $x 960$ Civil Rights Acts. See Lomax, The Kennedys Move in on Dixie, Harper's Magazine, May 1962, p. 27.

${ }^{305}$ De Tocqueville, Dexocracy in America 6, 7 (Commager ed. 1947).

${ }^{300}$ Id. at 310. 


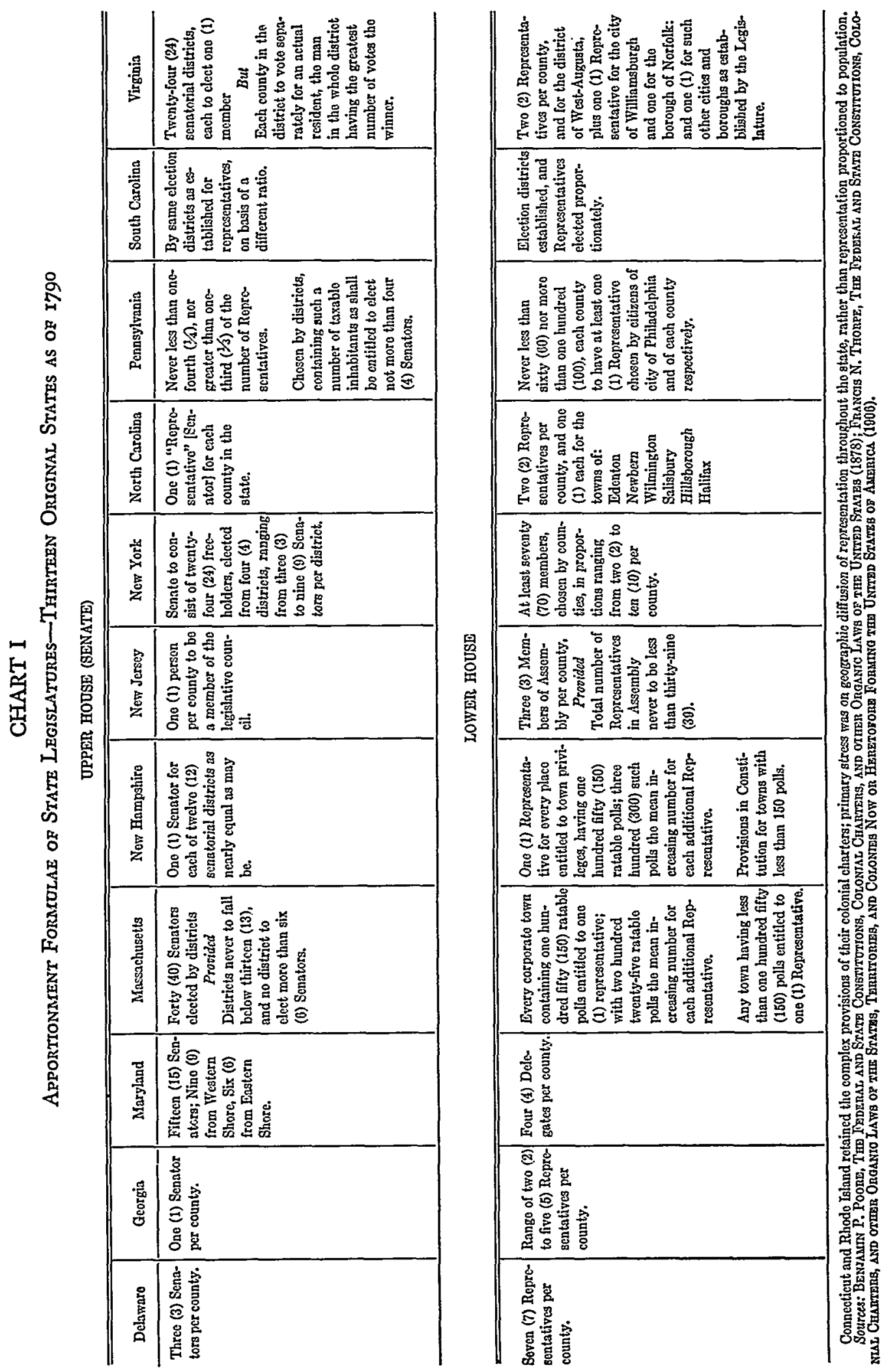




\section{CHART II}

Apportionment Formulae of State Legislatures-Thirteen Original States

AS OF $1865-70$

\begin{tabular}{|c|c|c|c|}
\hline Basis of Representation & Upper House (Senate) & Iower & Houso \\
\hline $\begin{array}{l}\text { 1. Representation Based on Geographic Unit Without Re- } \\
\text { gard To Population: } \\
\text { (a) Equal Representation for cach county. }\end{array}$ & $\begin{array}{l}\text { Delaware } \\
\text { New Jersey }\end{array}$ & Delatrare & (1) \\
\hline $\begin{array}{l}\text { (b) Equal Representation Based on Geographic Units } \\
\text { other than counties. }\end{array}$ & $\begin{array}{l}\text { Georgia } \\
\text { Massachusett3 } \\
\text { New York } \\
\text { Rhode Island }\end{array}$ & Connecticut & (1) \\
\hline $\begin{array}{l}\text { II. Representation Based On Geographic Unit With arINOR } \\
\text { Modifications Based On Population." }\end{array}$ & $\begin{array}{l}\text { Maryland } \\
\text { Pennsylvanis } \\
\text { South Carolins } \\
\text { Virginia }\end{array}$ & & (0) \\
\hline $\begin{array}{l}\text { III. Representation Proportioned To Units (county or dis- } \\
\text { trict) On Basis Of Population but with MAJOR limita- } \\
\text { tions to achieve geographic diffusion which may substan- } \\
\text { tially defeat population principle: e.g. (1) Minimum } \\
\text { limits, eg., rule that no unit may have less than one rep- } \\
\text { resentative, and, or, limitation on number of units which } \\
\text { may be combined to approximate one quota; (2) Maxi- } \\
\text { mum limits, eng., rule that no unit may have more than a } \\
\text { designated number of representatives; and (3) Low limit } \\
\text { (in relation to number of counties) on maximum size of } \\
\text { legislature when combined with minimum difusion } \\
\text { rules: }\end{array}$ & Connecticut & $\begin{array}{l}\text { Georgia } \\
\text { Maryland } \\
\text { Nerr Hampshiro } \\
\text { New Jersey } \\
\text { New York } \\
\text { North Carolina } \\
\text { Pennsylranis } \\
\text { Rhodo lsland } \\
\text { South Carolina } \\
\text { Virginia }\end{array}$ & (10) \\
\hline $\begin{array}{l}\text { IV. Representation To Be Apportioned On Population Basis } \\
\text { With Apparently MINOR Limitations, b.e }\end{array}$ & Net Hampehiro (1) & Massachusetts & (1) \\
\hline V. Population. & North Carolina & & (0) \\
\hline
\end{tabular}

- Some states may be classified to either II or III, depending on the weight given to special constitutional formulae. The diatinetion may not be vital bowerer, because the primary thrust of both II and IJI is toward georraphic diffusion, not representation by population. Some states charted in this category have special formulae not casily classifiable but weighted more to population principlo than to geographic diffusion. The heavier line between categories III and IV is desigaed to separate states using a strong gcograplio diffusion factor from states using a relatively unqualified population factor.

- Despite constitutional provisions appareptly sperilying apportionment by population, all siates in categorics IV and $V$ bavo population disparities between largest and smallest district at least exceeding $25 \%$, and in mest cases far exceeding that figure.

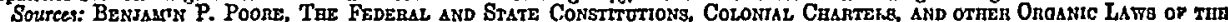
J Jited States (1878); Frances N. Thorpe, The Federal and State Construtions, Colonial Cgartzrs, and othed Ondanio Lawi

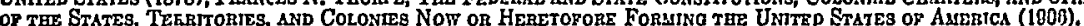

Comment: States other than the original thiteen were examined for the $1865-70$ period but many were nat chartable for a number of Comment: States other than the original thirteen were examined for the $1865-70$ period but many were not chartable for a number of reasnns, e.g. lack of cxplicitness in formal constitutional provisions coupled with lack of information on actual implementation; frcguent population principle; there was emphasis on geographic diffusion. 


\section{CHART III}

Apportionment Formulae of State Legislatures as of July I, rg6I

\begin{tabular}{|c|c|c|c|c|}
\hline Basis of Representation & \multicolumn{2}{|c|}{ Upper House (Senate) } & \multicolumn{2}{|c|}{ Lower House } \\
\hline $\begin{array}{l}\text { 1. Representation Based On Geographic Unit Without Re- } \\
\text { gard To Population: } \\
\text { (a) Equal Representation For Each County. }\end{array}$ & $\begin{array}{l}\text { Arizona } \\
\text { Idaho } \\
\text { Montana } \\
\text { Nevada }\end{array}$ & $\begin{array}{l}\text { New Jersey } \\
\text { New Mexico } \\
\text { South Carolina } \\
(7)\end{array}$ & & $(0)$ \\
\hline $\begin{array}{l}\text { (b) Equal Representation Based On Geographic Units } \\
\text { Other Than Counties (including districts initially } \\
\text { devised according to population but fixed in con- } \\
\text { etitution, e.g., Ark, N. D., Obla.) }\end{array}$ & $\begin{array}{l}\text { Arkansas } \\
\text { Delaware } \\
\text { Illinois } \\
\text { Michigan }\end{array}$ & $\begin{array}{l}\text { North Dakota } \\
\text { Oklahoma } \\
\text { (6) }\end{array}$ & $\begin{array}{l}\text { Delamare } \\
\text { Vermont }\end{array}$ & (2) \\
\hline $\begin{array}{l}\text { II. Representation Based on Geographic Dnit With MINOR } \\
\text { Mfodifications Based On Population." }\end{array}$ & $\begin{array}{l}\text { Hawaii } \\
\text { Maryland } \\
\text { Mississippi }\end{array}$ & $\begin{array}{l}\text { Ohio } \\
\text { (4) }\end{array}$ & & $(0)$ \\
\hline $\begin{array}{l}\text { III. Renresentation Proportioned To Units (county or dis- } \\
\text { trict) On Basis Of Population but with MAJOR limita- } \\
\text { tions to achieve geographic difusion which may substan- } \\
\text { tially defeat population principle: e.g., (1) Minimum } \\
\text { limits, c.g., rule that no unit may have less than one rep- } \\
\text { resentative, and, or, limitstion on number of units which } \\
\text { may be combined to approximate one quota; (2) Maxi- } \\
\text { mum limits, e.g., rule that no unit may have more than a } \\
\text { designated number of representatives; and (3) Low limit } \\
\text { (in relation to number of counties) on maximum size of } \\
\text { legislature when combined with minimum difusion rules.a }\end{array}$ & $\begin{array}{l}\text { Alabama } \\
\text { California } \\
\text { Connecticut } \\
\text { Florids } \\
\text { Georgia } \\
\text { Iowa } \\
\text { Louisians } \\
\text { Maine } \\
\text { Rhode Island } \\
\text { Texas } \\
\text { Utah (Low quota } \\
\text { sentative; m } \\
\text { additional r }\end{array}$ & $\begin{array}{l}\text { Vermont } \\
\text { Wyoming } \\
\text { (13) } \\
\\
\text { for 1st repre- } \\
\text { uch higher for } \\
\text { apresentative.) }\end{array}$ & $\begin{array}{l}\text { Alabama } \\
\text { Arizona } \\
\text { Arkansas } \\
\text { California } \\
\text { Connecticut } \\
\text { Florida } \\
\text { Georgia } \\
\text { Hawaii } \\
\text { Idaho } \\
\text { Iowa } \\
\text { Kansas } \\
\text { Louisiana } \\
\text { Maine } \\
\text { Maryland } \\
\text { Mississippi } \\
\text { Missouri }\end{array}$ & $\begin{array}{l}\text { Montana } \\
\text { Nerada } \\
\text { New Jersey } \\
\text { Nerr Mexico } \\
\text { New York } \\
\text { North Carolina } \\
\text { North Dakots } \\
\text { Ohio } \\
\text { Oklahoms } \\
\text { Pennsylrania } \\
\text { Rhode Island } \\
\text { South Carolina } \\
\text { Texas } \\
\text { Utah } \\
\text { West Virginia } \\
\text { Wyoming (32) }\end{array}$ \\
\hline \multirow[t]{2}{*}{$\begin{array}{l}\text { IV. Representation To Be Apportioned On Population Basis } \\
\text { With Apparently MINOR Limitations.b. }\end{array}$} & $\begin{array}{l}\text { Alaska } \\
\text { Missouri } \\
\text { New Hamphire } \\
\text { New York }\end{array}$ & $\begin{array}{l}\text { Oregon } \\
\text { Pennsylvania } \\
\text { South Dakota } \\
\text { (7) }\end{array}$ & $\begin{array}{l}\text { Alaska } \\
\text { New Hampshire } \\
\text { (Taxbasis; appea } \\
\text { to avoid gross } \\
\text { inequity.) }\end{array}$ & $\begin{array}{l}\text { Oregon } \\
\text { South Dakota } \\
\text { (4) }\end{array}$ \\
\hline & \multicolumn{4}{|c|}{ NEBRASKA } \\
\hline V. Population.0 & $\begin{array}{l}\text { Colorado } \\
\text { Indiana } \\
\text { Kansas } \\
\text { Kentucky } \\
\text { Massachusetts } \\
\text { Minnesota } \\
\text { North Carolina }\end{array}$ & $\begin{array}{l}\text { Tennessee } \\
\text { Virginia } \\
\text { Washington } \\
\text { West Virginia } \\
\text { Wisconsin } \\
\text { (13) }\end{array}$ & $\begin{array}{l}\text { Colorado } \\
\text { Mlinois } \\
\text { Indiana } \\
\text { Kentucky } \\
\text { Massachusetts } \\
\text { Michigan } \\
\text { Minnesota }\end{array}$ & $\begin{array}{l}\text { Tennessee } \\
\text { Virginia } \\
\text { Tashington } \\
\text { Wisconsin } \\
\text { (12) }\end{array}$ \\
\hline
\end{tabular}

a Some states may he classified to either II or III, depending on the weight given to special constitutional formulae. The distinction mag not be vital however, because the primary thrust of both Il and III is toward gecgraphic diffusion, not representation by population. (1) is designed to separate states using a strong geographic difusion factor from states using a relatively unqualified population factcr.

- Despite constitutional provisions aprarently specifying apportionment by population, all states in categories $\Gamma$ and $V$ have population disparities between largest and smallest district at least exceeding $25 \%$, and in most cases far exceeding that figure.

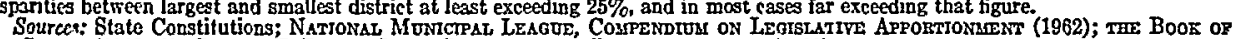

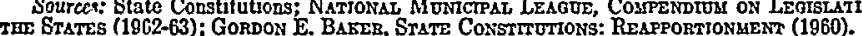

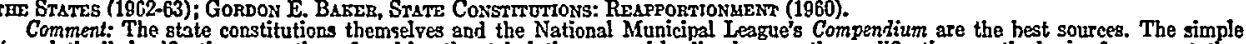
"population" classifications sometimes found in nther tabulations are misleading because the qualifications on the basis of representation noted under I (b) and III in this chart are often ignored. 


\section{CHART IV}

Regional Comparisons of Representation in the United Stattes House of Representatives

\begin{tabular}{|c|c|c|c|c|}
\hline $\begin{array}{c}\text { Predominant Characteristic } \\
\text { of Population }\end{array}$ & $\begin{array}{l}\text { Number of } \\
\text { Districts in } \\
\text { Group }\end{array}$ & $\begin{array}{l}\text { Total Population } \\
\text { of Districts } \\
\text { in Group }\end{array}$ & $\begin{array}{c}\text { Average } \\
\text { District } \\
\text { Population }\end{array}$ & $\begin{array}{l}\text { Relative Values } \\
\text { of the Voto } \\
(100=\text { averago })\end{array}$ \\
\hline
\end{tabular}

\begin{tabular}{|c|c|c|c|c|}
\hline \multicolumn{5}{|c|}{ The United States } \\
\hline 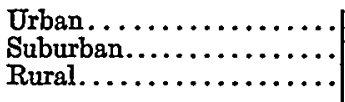 & $\begin{array}{r}126 \\
60 \\
250\end{array}$ & $\begin{array}{l}54,427,014 \\
32,902,170 \\
91,230,035\end{array}$ & $\begin{array}{l}431,960 \\
548,370 \\
364,920\end{array}$ & $\begin{array}{r}95 \\
75 \\
112\end{array}$ \\
\hline $\begin{array}{l}\text { National Total (excludes } \\
\text { District of Columbia). }\end{array}$ & $436^{*}$ & $178,559,219$ & 408,602 & \\
\hline
\end{tabular}

Easterk States

(Conn., Del., Maine, Md., Mass., N. H., N. J., N. Y., Pa., R. I., Vt., W. Va.)

\begin{tabular}{|c|c|c|c|c|}
\hline 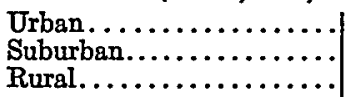 & $\begin{array}{l}46 \\
33 \\
49\end{array}$ & $\begin{array}{l}16,471,438 \\
15,885,354 \\
17,728,429\end{array}$ & $\begin{array}{l}358,075 \\
481,374 \\
361,805\end{array}$ & $\begin{array}{r}109 \\
81 \\
108\end{array}$ \\
\hline Regional Total.. & 128 & $50,085,221$ & 391,291 & \\
\hline
\end{tabular}

Sotthern States

(Ala., Ark., Fla., Ga., Ky., La., Miss., N. C., Okla., S. C., Tenn., Texas, Va.)

\begin{tabular}{|c|c|c|c|c|}
\hline 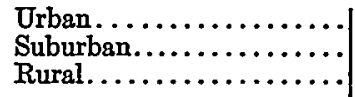 & $\begin{array}{r}24 \\
9 \\
91\end{array}$ & $\begin{array}{r}13,367,384 \\
2,995,411 \\
32,438,960\end{array}$ & $\begin{array}{l}556,974 \\
599,082 \\
356,472\end{array}$ & $\begin{array}{r}73 \\
68 \\
114\end{array}$ \\
\hline Regional Total. & 120 & $48,801,755$ & 406,681 & \\
\hline
\end{tabular}

Midwestern STATEs

(IIl., Ind., Iowa, Kan., Mich., Minn., Mo., Neb., N. D., Ohio, S. D., Wis.)

\begin{tabular}{|c|c|c|c|c|}
\hline 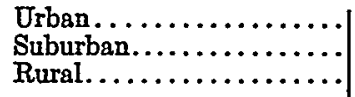 & $\begin{array}{l}36 \\
12 \\
81\end{array}$ & $\begin{array}{r}15,329,068 \\
7,285,536 \\
29,004,535\end{array}$ & $\begin{array}{l}425,807 \\
607,128 \\
358,081\end{array}$ & $\begin{array}{r}94 \\
66 \\
112\end{array}$ \\
\hline Regional Total. & 129 & $51,619,139$ & 400,148 & \\
\hline
\end{tabular}

Western STAtes

(Alaska, Ariz., Calif., Colo., Hawaii, Idaho, Mont., Nev., N. M., Oro., Jtah, Wash., Wyo.)

\begin{tabular}{|c|c|c|c|c|}
\hline 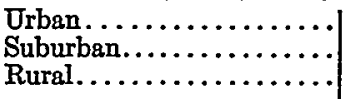 & $\begin{array}{l}20 \\
10 \\
29\end{array}$ & $\begin{array}{r}9,259,124 \\
6,735,869 \\
12,058,111\end{array}$ & $\begin{array}{l}462,956 \\
673,587 \\
415,797\end{array}$ & $\begin{array}{r}103 \\
71 \\
114\end{array}$ \\
\hline Regional Total.......... & 59 & $28,053,104$ & 475,476 & \\
\hline
\end{tabular}

*Actual House membership is currently 437. The "unclassifiable" At-Large seat from Connecticut is axciuded from theso counts. Source: Reproduced with permission from Congressional Quarterly Weekly Keport. Feb. 2, 1062, p. 163. 


\section{CHART V}

Value of Cittzens' Votes for the State Legislatures, I9I0-1960 I00 $=$ Average Vote Value

\begin{tabular}{|c|c|c|c|c|}
\hline $\begin{array}{l}\text { Categories of Counties by } \\
\text { Population Size }\end{array}$ & $\begin{array}{c}\text { Number of Counties } \\
\text { in Category }\end{array}$ & $\begin{array}{l}\text { Total Population of } \\
\text { Counties in Category }\end{array}$ & $\begin{array}{c}\text { \% of National } \\
\text { Population }\end{array}$ & Vote Value \\
\hline $\begin{array}{c}\text { Under } 25,000 \ldots \ldots \ldots \\
25,000-99,999 \ldots \ldots \ldots \\
100,000-199,999 \ldots \ldots \ldots \\
500,000 \text { and over......... }\end{array}$ & $\begin{array}{r}1,942 \\
884 \\
238 \\
64\end{array}$ & $\begin{array}{r}960 \\
23,064,000 \\
41,247,000 \\
48,542,000 \\
65,705,000\end{array}$ & $\begin{array}{l}12.9 \\
23.1 \\
27.2 \\
36.8\end{array}$ & $\begin{array}{r}171 \\
123 \\
81 \\
76\end{array}$ \\
\hline $\begin{array}{r}\text { Under } 25,000 \ldots \ldots \ldots \\
25,000-99,999 \ldots \ldots \ldots \\
100,000-499,999 \ldots \ldots \ldots \\
500,000 \text { and over......... }\end{array}$ & $\begin{array}{r}1,954 \\
901 \\
200 \\
41\end{array}$ & $\begin{array}{l}24,261,000 \\
40,757,000 \\
40,088,000 \\
44,789,000\end{array}$ & $\begin{array}{l}16.2 \\
27.2 \\
26.7 \\
29.9\end{array}$ & $\begin{array}{r}141 \\
114 \\
83 \\
78\end{array}$ \\
\hline $\begin{array}{c}\text { Under } 25,000 \ldots \ldots \ldots \\
25,000-99,999 \ldots \ldots \ldots \\
100,000-499,999 \ldots \ldots \ldots \\
500,000 \text { and over......... }\end{array}$ & $\begin{array}{r}2,062 \\
869 \\
142 \\
23\end{array}$ & $\begin{array}{l}26,331,000 \\
37,411,000 \\
29,911,000 \\
28,634,000\end{array}$ & $\begin{array}{l}21.5 \\
30.6 \\
24.5 \\
23.4\end{array}$ & $\begin{array}{r}131 \\
109 \\
84 \\
74\end{array}$ \\
\hline $\begin{array}{r}\text { Under } 25,000 \ldots \ldots \ldots \\
25,000-99,999 \ldots \ldots \ldots \\
100,000-199,999 . \ldots \ldots \ldots \\
500,000 \text { and over......... }\end{array}$ & $\begin{array}{r}2,149 \\
796 \\
87 \\
15\end{array}$ & $\begin{array}{l}27,421,000 \\
32,203,000 \\
17,154,000 \\
14,853,000\end{array}$ & $\begin{array}{l}29.9 \\
35.1 \\
18.7 \\
16.2\end{array}$ & $\begin{array}{r}113 \\
103 \\
91 \\
81\end{array}$ \\
\hline
\end{tabular}

Source: Reproduced with permission from Congressional Quarterly Weekly Report, Feb. 2, 1962, p. 170, as adapted from statistics in Paul T. Dafid \& Ralph Eisendera, Defaldation of the Úban and Suburbay Vote (1961). 